\title{
DNA, SPECTROSCOPIC AND GEOCHEMICAL ANALYSES OF BONE FRAGMENTS AND ASSOCIATED SPELEOTHEMS IN POSTOJNA CAVE, SLOVENIA
}

\author{
DNA, SPEKTROSKOPSKA IN GEOKEMIJSKA ANALIZA \\ FRAGMENTOV KOSTI IN Z NJIMI POVEZANIH SIGINIH TVORB \\ V POSTOJNSKI JAMI, SLOVENIJA
}

\author{
Matej LIPAR ${ }^{1, *}$, Irena ZUPANIČ PAJNIČ ${ }^{2, *}$, Marko COTMAN $^{3}$, Jelka ZABAVNIK PIANO ${ }^{3}$, \\ Jian-xin $\mathrm{ZHAO}^{4}$, Dean PEKAROVIČ ${ }^{5} \&$ Tamara LESKOVAR ${ }^{6}$
}

\begin{abstract}
UDC 577.21:591.471:552.545(497.4Postojna) Matej Lipar, Irena Zupanič Pajnič, Marko Cotman, Jelka Zabavnik Piano, Jian-xin Zhao, Dean Pekarovič \& Tamara Leskovar: DNA, spectroscopic and geochemical analyses of bone fragments and associated speleothems in Postojna cave, Slovenia

Loose bone fragments coated with calcite precipitate including a loose/broken stalagmite containing small fragments of cemented bones were collected from the Postojna Cave to investigate whether deoxyribonucleic acid (DNA) can be determined. The study is complemented by the Fourier-transform infrared spectroscopy - attenuated total reflectance (FTIR-ATR) analysis in order to determine the alteration of the bones and to test whether this analysis can be used as an indicator of possible DNA preservation. In addition, geochemical analyses were conducted in order to determine whether the associated flowstone/stalagmite is suitable for elucidating the timing of bone thanatocoenosis and further palaeoenvironmental analyses. The organic matter (collagen) is poorly preserved. However, we succeeded in amplifying a $94 \mathrm{bp}$ long fragment of the cytochrome $\mathrm{b}$ (Cyt b) gene of mitochondrial DNA (mtDNA) in polymerase chain reaction (PCR) for one sample, and in sequencing the am-
\end{abstract}

\begin{abstract}
Izvleček UDK 577.21:591.471:552.545(497.4Postojna) Matej Lipar, Irena Zupanič Pajnič, Marko Cotman, Jelka Zabavnik Piano, Jian-xin Zhao, Dean Pekarovič \& Tamara Leskovar: DNA, spektroskopska in geokemijska analiza fragmentov kosti in z njimi povezanih siginih tvorb $v$ Postojnski jami, Slovenija

Iz Postojnske jame so bili vzeti delci kosti, prevlečeni s kalcitno skorjo, vključno $\mathrm{z}$ odlomljenim stalagmitom, $\mathrm{v}$ katerem so zacementirani drobci kosti, da bi se ugotovilo, ali je mogoče določiti deoksiribonukleinsko kislino (DNA). Študijo dopolnjuje analiza s Fourierevo transformacijsko infrardečo spektroskopijo z zmanjšanim popolnim odbojem (FTIR-ATR), ki je bila izvedena, da se ugotovijo biokemične spremembe v kosteh in se preveri, ali je mogoče to analizo uporabiti kot kazalnik morebitne ohranjenosti DNA. Izvedene so bile tudi geokemijske analize, da bi ugotovili, ali je pripadajoča siga primerna za razlago časa kostne tanatocenoze in nadaljnje paleookoljske analize. Organska snov (kolagen) je slabo ohranjena. Pri enem vzorcu nam je z verižno reakcijo s polimerazo (PCR) uspelo pomnožiti 94 bp dolg fragment gena za citokrom b (Cyt b) mitohondrijske DNA (mtDNA) in pomnožene produkte smo uspešno sekvencirali. Dobljeno zaporedje dolžine 70 bp ustreza zaporedju Cyt
\end{abstract}

${ }^{1}$ Anton Melik Geographical Institute, Research Centre of the Slovenian Academy of Sciences and Arts, Gosposka ulica 13, 1000 Ljubljana, Slovenia, e-mail: matej.lipar@zrc-sazu.si

${ }^{2}$ Institute of Forensic Medicine, Faculty of Medicine, University of Ljubljana, Korytkova 2, 1000 Ljubljana, Slovenia, e-mail: irena. zupanic@mf.uni-lj.si

${ }^{3}$ Institute of Preclinical Sciences, Veterinary Faculty, University of Ljubljana, Gerbičeva 60, 1000 Ljubljana, Slovenia, e-mail: marko.Cotman@vf.uni-lj.si

${ }^{3}$ Institute of Preclinical Sciences, Veterinary Faculty, University of Ljubljana, Gerbičeva 60, 1000 Ljubljana, Slovenia, e-mail: Jelka. ZabavnikPiano@vf.uni-lj.si

${ }^{4}$ Radiogenic Isotope Facility, School of Earth and Environmental Sciences, The University of Queensland, Brisbane, QLD 4072, Australia, e-mail: j.zhao@uq.edu.au

${ }^{5}$ Clinical Radiology Institute, UMC Ljubljana, Zaloška 7, Ljubljana, Slovenia, e-mail: dean.pekarovic@kclj.si

${ }^{6}$ Department of Archaeology, Faculty of Arts, University of Ljubljana, Zavetiška 5, Ljubljana, Slovenia, e-mail: Tamara.Leskovar@ ff.uni-li.si

* Corresponding Author

Received/Prejeto: 07.02.2020

DOI: $10.3986 /$ ac.v49i2-3.7970 
plified products. The $70 \mathrm{bp}$ long sequence obtained corresponds to that of the Cyt $b$ of the cave bear (Ursus deningeri or Ursus spelaeus sensu lato). The uranium-thorium dating of the speleothem covering the bones revealed its thanatocoenosis occurred prior to $55 \mathrm{ka}$, most likely in the late marine isotope stage 4 or early marine isotope stage 3 . High porosity and recrystallisation of the flowstone/stalagmite at this part of the cave prevent high-resolution palaeoclimatic interpretation; however, low-resolution stable isotope geochemistry suggests a steppe-like environment during the subsequent growth of the speleothem.

Key words: palaeoclimate, stalagmite, Ursus, karst, palaeontology, cave bear, deoxyribonucleic acid. $b$ jamskega medveda (Ursus deningeri ali Ursus spelaeus sensu lato). U-Th datacija sige, ki pokriva kosti, nakazuje, da se je tanatocenoza pojavila pred $55 \mathrm{ka}$, najverjetneje $\mathrm{v}$ fazi MIS 4 ali MIS 3. Visoka poroznost in rekristalizacija sige v tem delu jame preprečujeta paleoklimatsko interpretacijo visoke ločljivosti, geokemija stabilnih izotopov $\mathrm{z}$ nizko ločljivostjo pa nakazuje na stepi podobno okolje.

Ključne besede: paleoklima, stalagmit, Ursus, kras, paleontologija, jamski medved, deoksiribonukleinska kislina.

\section{INTRODUCTION}

Caves are natural laboratories for palaeoenvironmental studies; archives such as clastic and chemogenic sediments (e.g., bones, flood sediments, speleothems) have proved to be valuable palaeo-environmental archives with a variety of proxies (e.g., stable isotopes, pollen) (Fairchild \& Baker 2012; Jones et al. 2020). In accordance, diverse passages in Postojna Cave have been providing excellent underground palaeo-environmental indications (Genty et al. 1998; Zupan Hajna et al. 2008; Mandić 2013; Ferk 2016; Domínguez-Villar et al. 2018; Ferk et al. 2019).

Although there have been numerous findings of animal bones within the cave's sediments (Brodar 1966), precise dating has not been undertaken, and no attempt has been made to combine a bone study with environmental information from the adjacent flowstone or stalagmite. Species identification of small fragments within the flowstone is difficult due to their generally small size, but knowledge of DNA of the animal species the bones belong to, can contribute to a better understanding of past environments (Rawlence et al. 2014). One of the approaches is a DNA test, but preservation of DNA in ancient bones is affected by the environment to which the bones are subjected (Pawłowska et al. 2014). The most important environmental factors are the temperature, humidity, $\mathrm{pH}$ and geochemical properties of the sediments, and the presence of microorganisms (Höss et al. 1996; Poinar et al. 1996; Putkonen et al. 2010; Higgins \& Austin 2013). The key factors for DNA preservation are ambient temperature and humidity, with highly stable environments showing little annual fluctuation in temperature or humidity are favourable for preservation. Warm, wet environments are expected to dramatically increase the thermal age of ancient DNA, resulting in extensive damage and fragmentation (Smith et al. 2003). On the other hand, alternating dry and humid environments, and environments with continual water flow, are more harmful to DNA preservation than a continuously wet environment (Turner-Walker 2008; Higgins \& Austin 2013; Kendall et al. 2018).

The aim of this paper is to identify for the first time the animal species of the bones in Postojna Cave by the extraction and sequence analysis of DNA. Concurrently, the paper tested whether the Fourier-transform infrared spectroscopy - attenuated total reflectance (FTIR-ATR) coupled with petrographic thin-section analysis can preliminary indicate the level of bone preservation for DNA test, and whether the flowstone and stalagmite, associated with bone fragments, can be used to elucidate the timing and environmental conditions at the time of bone thanatocoenosis using geochemical analysis of uranium, thorium, oxygen and carbon isotopes of the stalagmite.

\section{REGIONAL SETTING}

Southwestern Slovenia is famous for its geo-diversity (Perko et al. 2015, 2017) due to carbonate bedrock particularly affected by karst processes, resulting in numerous world-class karst phenomena. These include the Postojna Cave System, one of the longest cave systems in Slovenia with $24 \mathrm{~km}$ of surveyed passages and multi- ple entrances (Cave Cadastre 2019) (Fig. 1). The cave has been managed as a show cave for more than 200 years (Shaw \& Cuk 2015) and is now one of the most recognised and visited caves in Europe. Cave exploration and scientific research date back to the $17^{\text {th }}$ century and its diversity of passages contributes to ongoing scientific pro- 


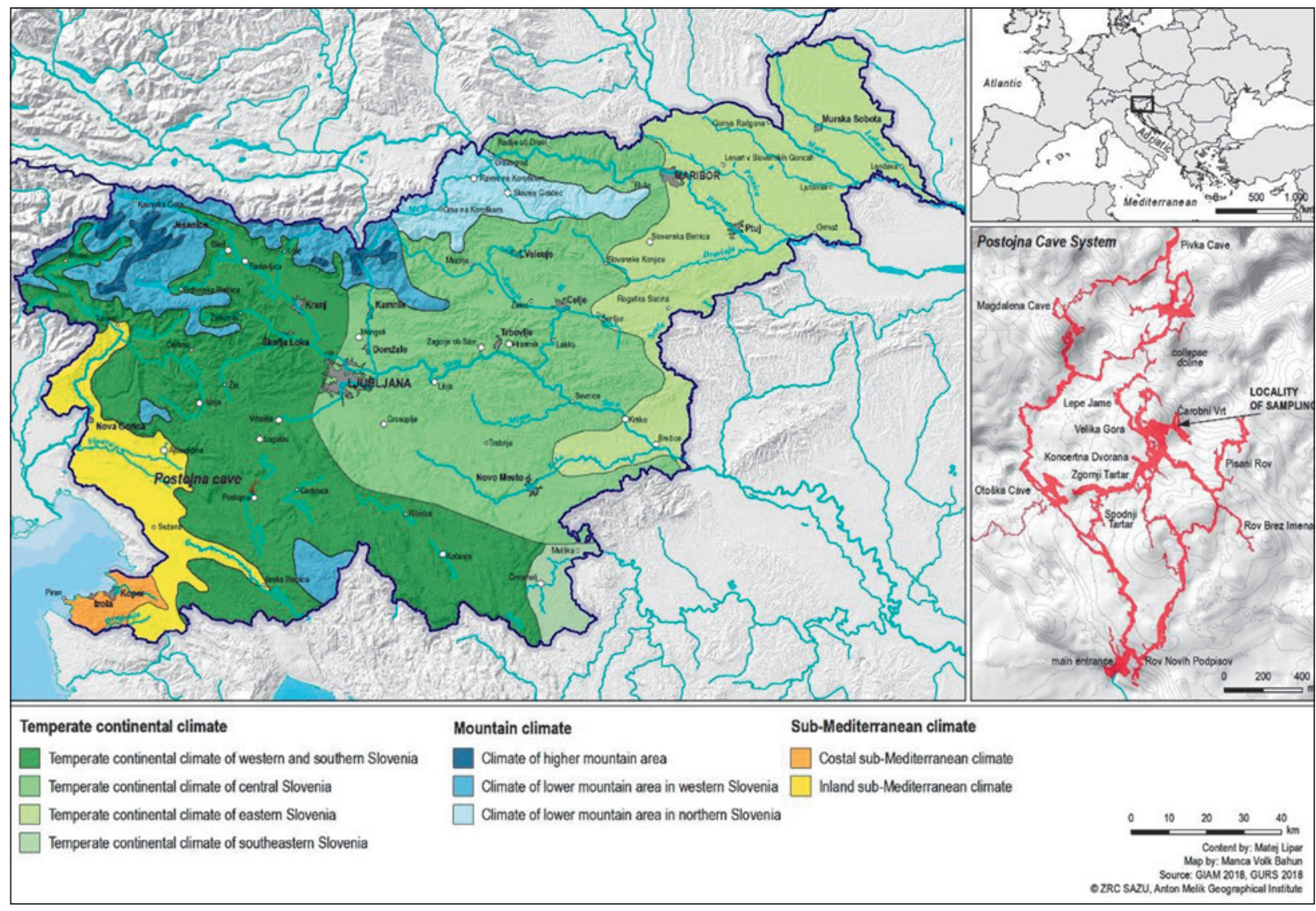

Fig. 1: Locality map of Postojna Cave System.

gress in geology, karstology, biology and palaeoclimate (Valvasor 1689; Hohenwart 1830; Schmidl 1854; Perko 1910; Brodar 1966; Gams 1968; Brodar 1969; Gospodarič 1969, 1971; Ikeya et al. 1983; Šebela 1998; Šebela \& Sasowsky 1999; Mihevc 2002; Stepišnik 2004; Ferk 2016; Domínguez-Villar et al. 2018; Ferk et al. 2019; Pipan et al. 2019; Zupan Hajna et al. 2019).
Postojna Cave is one of the most visited show caves on the worldwide scale and is situated in a transitional climatic zone between continental and Mediterranean climatic conditions controlled by air masses sourced from the Mediterranean Sea (Komac et al. 2020). The main entrance of the cave is a ponor of the Pivka River flowing from impermeable Eocene flysch and sinking

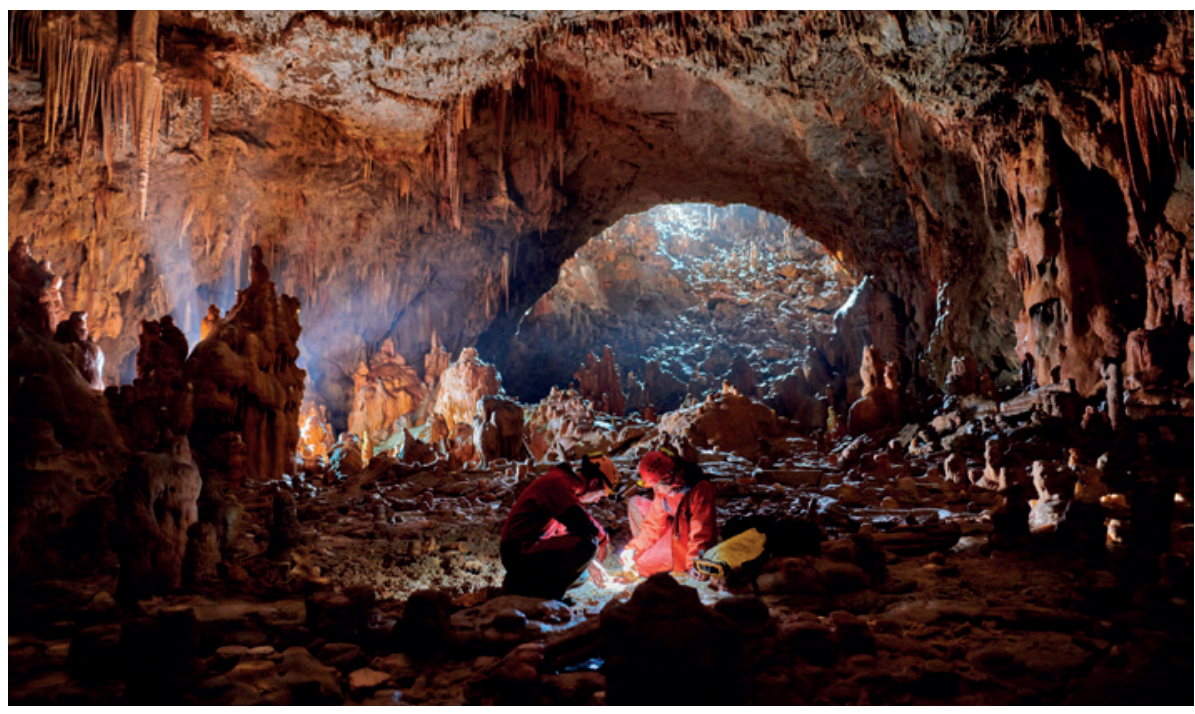

Fig. 2: The lower part of the Čarobni Vrt passage with scattered loose fragments of bones. (Photo: I. Medja). 
into the karstified Upper Cretaceous limestone (Buser et al. 1967; Šebela 1998; Pleničar et al. 2009; Stepišnik 2017). Two main levels of cave passages characterise the present cave as epiphreatic and annually flooded (lower level) as well as vadose and hydrologically inactive (higher level) (Gospodarič \& Habič 1966). The latter still preserve remnants of enhanced solution by turbulent flow (e.g., scallops) and interchanging fluvial and chemogenic sediments revealing a hydrologically dynamic evolution during speleogenesis.

Palaeomagnetic analyses in Postojna Cave have re- vealed an age range of clastic/fluvial sediments from recent to up to $2.15 \mathrm{Ma}$ (Šebela \& Sasowsky 1999; Zupan Hajna et al. 2008; Zupan Hajna et al. 2019). Such sediments are in places intersected by sequences of flowstone, remnants of Pleistocene fauna (e.g., cave bear and hippopotamus) and stone tools of Palaeolithic culture (Rakovec 1954; Brodar 1966; Brodar 1969; Ferk 2016; Ferk et al. 2019).

Skeletal remnants of a cave bear (Ursus spelaeus Rosenm.) were found in Čarobni Vrt passage of the cave (Fig. 1), leading to the excavation of a small profile, described in detail by Brodar (1966).

\section{MATERIALS AND METHODS}

Loose bone fragments coated with calcite precipitate including a loose/broken stalagmite containing small fragments of cemented bones were recovered from the Postojna Cave. They were found scattered in the relatively near $(2-5 \mathrm{~m})$ surroundings of the dug profile (see Brodar (1966) for details) in a lowest point of the passage, characterised by a slight depression (Fig. 2). In general, the entire floor is largely covered with flowstone, stalagmites and fallen stalactites, most of which are fissured. Remnants of flowstone around 1 to 2 meters above the present ground of the depression indicate its formation after the flowstone deposition. The active flowstone deposition in current times is absent. The bones appear to be associated with the primary commencement time of flowstone deposition, which occurred on the top of the flysch-mud sediments. The flowstone crust sinks into the underlying flysch-mud sediment, that in present also partly appears on the top of the flowstone due to remobilisation through fissures. However, Brodar (1966) also suggested the less likely possibility that the flowstone could have formed earlier, lost its original sediment underneath, and the empty space later filled up with flysch sediment underneath and also partly above. Nevertheless, the bones have been found coated with/cemented within the flowstone, meaning their thanatocoenosis belongs to the commencement time of flowstone deposition or earlier.

For the purpose of annual temperature variation, temperature monitoring of the Čarobni Vrt passage was implemented using a Tinytag Plus 2 temperature data logger on an hourly interval in March 2018. The logger was installed on a plastic wire to prevent contact with the floor or wall of the passage. As the samples were found loose and scattered in the area, their original orientation and position are unknown. The reason the samples were loose could be due to ground subsidence as it is noted by remnants of previous flowstone-covered grounds around 1 to 2 meters above the present ground, or anthropogenic activities.

A computed tomography scan (CT) was performed with Siemens Dual Source CT Somatom Force on all the samples at the Institute of Radiology, University Medical Centre (UMC) Ljubljana, Slovenia prior to cutting and drilling to preserve original data on intact bone and flowstone structures. CT offers a non-destructive method for visualising the internal structure of materials. Whilst it provided general preliminary guide for sampling, it was mostly performed to record and archive the data (including visual aspects of the bone and flowstone coating relationship) as the following DNA, FTIR-ATR and geochemical analyses used destructive methods requiring cutting and drilling of samples.

The X-ray beam was orientated perpendicular to the object and according to the beam spectrum and attenuation coefficient of scanned materials the data was processed in the detector system. Dual Energy protocol was used to get better spectral separation of composition; postero-anterior (PA) and lateral (LAT) direction with tube voltage set to $120 \mathrm{kV}$ and a tube current of $20 \mathrm{~mA}$. For exposure parameters we chose a detector collimation of $128 \times 0.6 \mathrm{~mm}$ with a tube voltage of $100 \mathrm{kV}$ and a quality reference $\mathrm{mA}$ of 190 for the $1^{\text {st }} \mathrm{X}$-ray tube, and $150 \mathrm{Sn}$ (radiographic technique when additional $\mathrm{Sn}$ filter is used for the primary X-ray beam) and $380 \mathrm{~mA}$ for the $2^{\text {nd }} \mathrm{X}$ ray tube. For the final analysis, we used a slice thickness $1.0 \mathrm{~mm}$ with $0.7 \mathrm{~mm}$ increment images with a tube voltage $\mathrm{kV} 150 \mathrm{Sn}$.

Furthermore, to preserve the detail 3D visual image of each sample, the samples were individually photographed multiple times on a rotating plate, capturing the variety of view-angles. The photos were used to create a 3D image using Agisoft PhotoScan software. 


\section{SAMPLE PREPARATION}

\section{Bone fragments}

Five fragments of animal bone samples with distinctive outer cortical and inner trabecular parts (sample Bn5, Bn14, Bn15, Bn16 and Bn21) were used for the study (Figs. 3-7).

A fragment of compact bone tissue was cut out of each sample for FTIR-ATR and DNA analyses. Washing in bi-distilled water, detergent and ethanol and radiation with UV light was performed to reduce contamination from the previous handling according to Wilson et al. (1995). Additionally, removing the bone surface by drilling and acquiring the bone material directly from the inside of the specimen was employed (Amory et al. 2012). Cleaning and grinding the bones took place in a room designed exclusively for processing old skeletal remains using a closed microbiological safety cabinet MC 3 (Iskra Pio, Šentjernej, Slovenia, EU). Drilling, cutting, and grinding were performed with strict precautions recommended by Carracedo et al. (2000) and Pääbo et al. (2004), including protective clothing (sterile dispos-

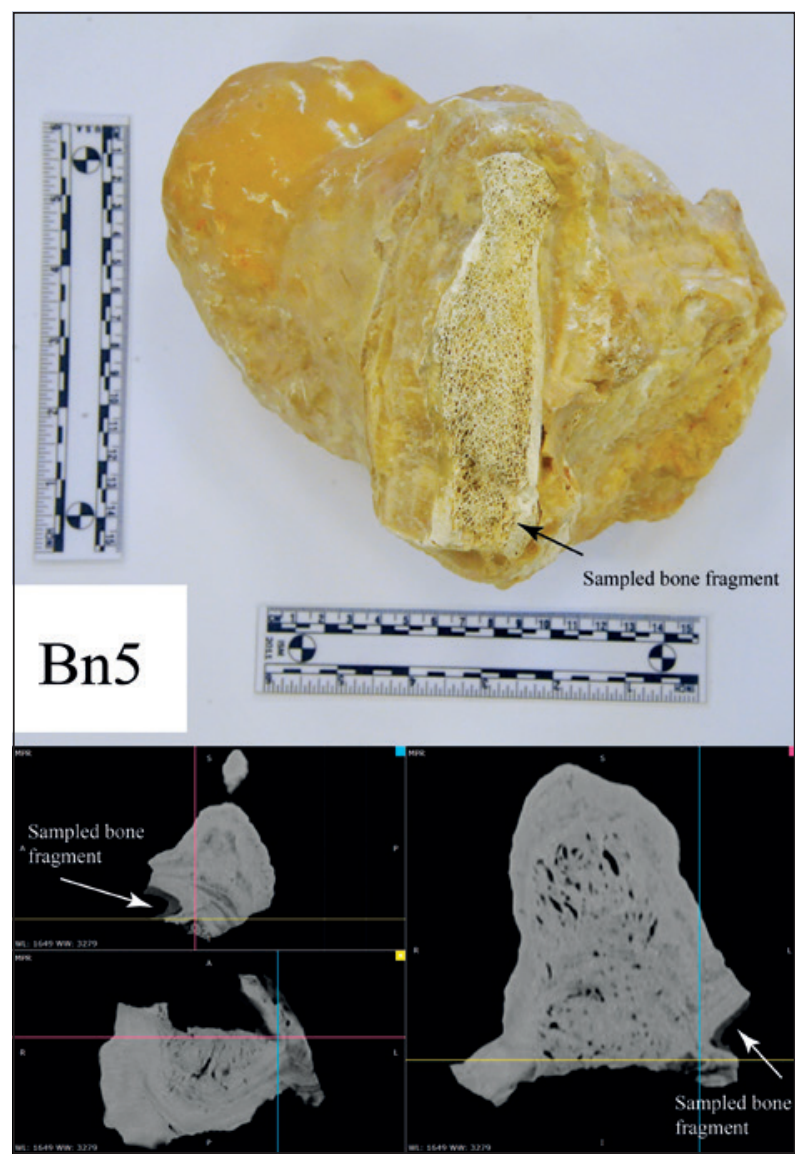

Fig. 3: Photograph and CT scans of the analysed Bn05 sample (stalagmite). This sample is relatively large in comparison to others. For detailed scan of its polished side, see Fig. 12. able coat, cap, mask, double latex gloves) and equipment and surfaces treated with bleach and irradiated with UV light. All sample processing was carried out in laminar flow cabinets equipped with HEPA filters and UV lights. The entire working place and the tools for processing the bones were cleaned by washing with bleach (6\% sodium hypochlorite (Sigma-Aldrich, St. Louis, MO, USA)), sterile bi-distilled water (Millipore, Darmstadt, Germany) and $80 \%$ ethanol (Fisher Scientific, Leics, UK) and UV irradiated for 72 hours as proposed by Rohland \& Hofreiter (2007).

Bone samples were cleaned mechanically (physical removal of the surface using a rotary sanding tool (Dremel, Racine, WI, USA) and chemically (washing in 5\% Alconox detergent (Sigma-Aldrich)), sterile bi-distilled water (Millipore) and 80\% ethanol (Fisher Scientific), irradiated with UV light for 30-min and grinded into a powder. A layer of approximately 1 to $3 \mathrm{~mm}$ was removed from the surface of the bone by sanding. A clean piece of bone was cut with a diamond disk attached to a drill. To prevent the bone-warming during drilling and cutting, a lower speed setting was used for abrasion and cutting, combined

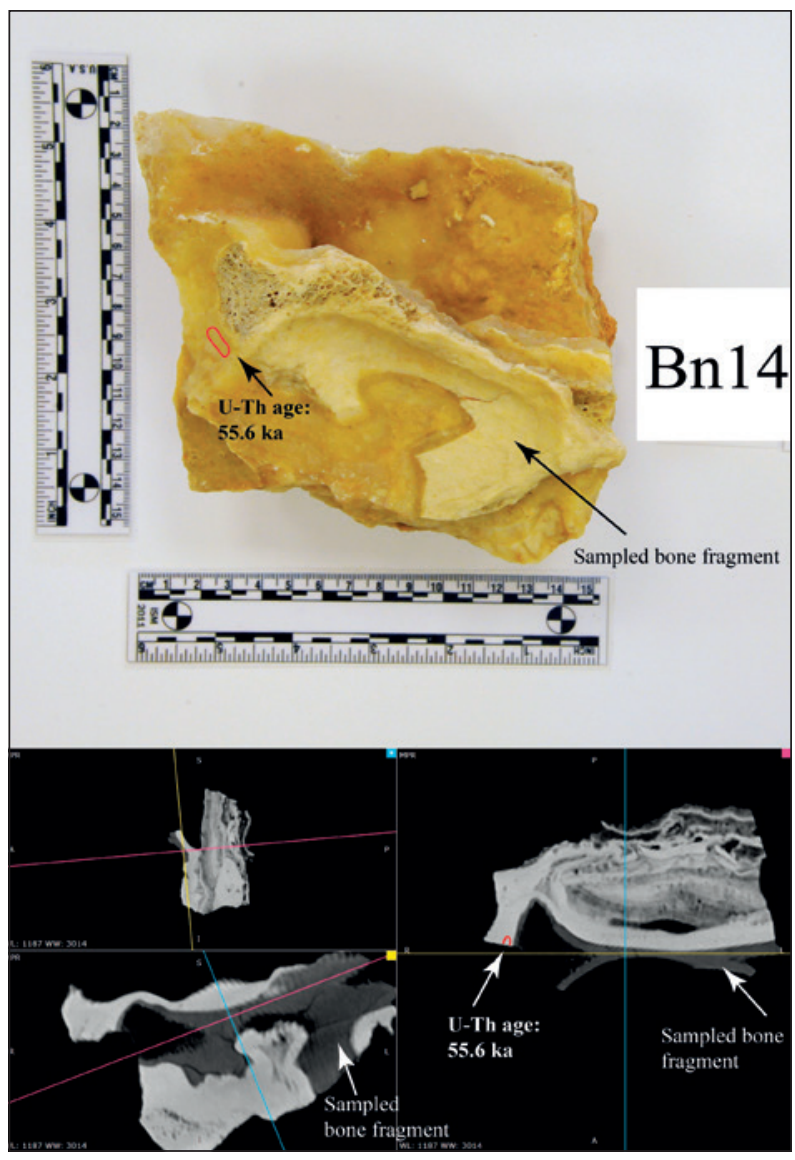

Fig. 4: Photograph and CT scans of the analysed Bn14 sample. 


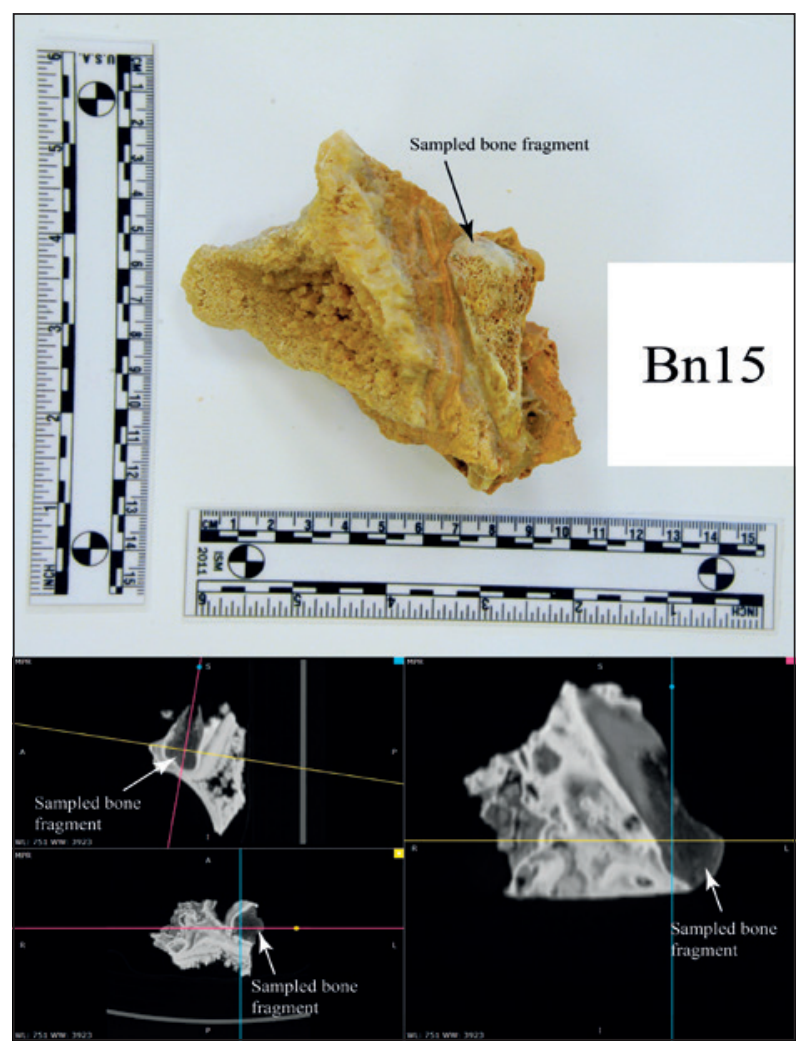

Fig. 5: Photograph and CT scans of the analysed Bn15 sample.

with frequently cooling of the bone in liquid nitrogen. The samples were left to dry overnight at room temperature prior to grinding into a powder. To avoid cross-contamination among samples a different set of equipment was used for each sample. The tissue homogenizer Bead Beater MillMix 20 (Tehtnica - Domel, Železniki, Slovenia) with $25 \mathrm{ml}$ metal grinding vials and metal balls $20 \mathrm{~mm}$ in diameter was used to obtain a fine powder with very small pieces from animal bones. Bone samples were grounded for $1 \mathrm{~min}$ at a frequency of $30 \mathrm{~Hz}$ and up to $4 \mathrm{~g}$ of sample was pulverized. The powder obtained was placed in a sterile tube and used for mtDNA analyses. Grinding vials were thoroughly cleaned before reuse by washing with water, detergent, sterile bi-distilled water and $80 \%$ ethanol. Clean grinding vials were packed in a bag for sterilization then sterilized by UV irradiation at least overnight or up to 72 hours and additionally $30 \mathrm{~min}$ before use. The grinding device provides a high-quality bone powder suitable for the extraction of genomic DNA from ancient bones.

\section{Flowstone and stalagmite}

After the extraction of bone fragments, the flowstone coating of the sample Bn14 and a stalagmite (sample Bn5) were used for dating. Additionally, the stalagmite was cut parallel to its growth axis and polished. One polished surface was used for hand-drilling powdered

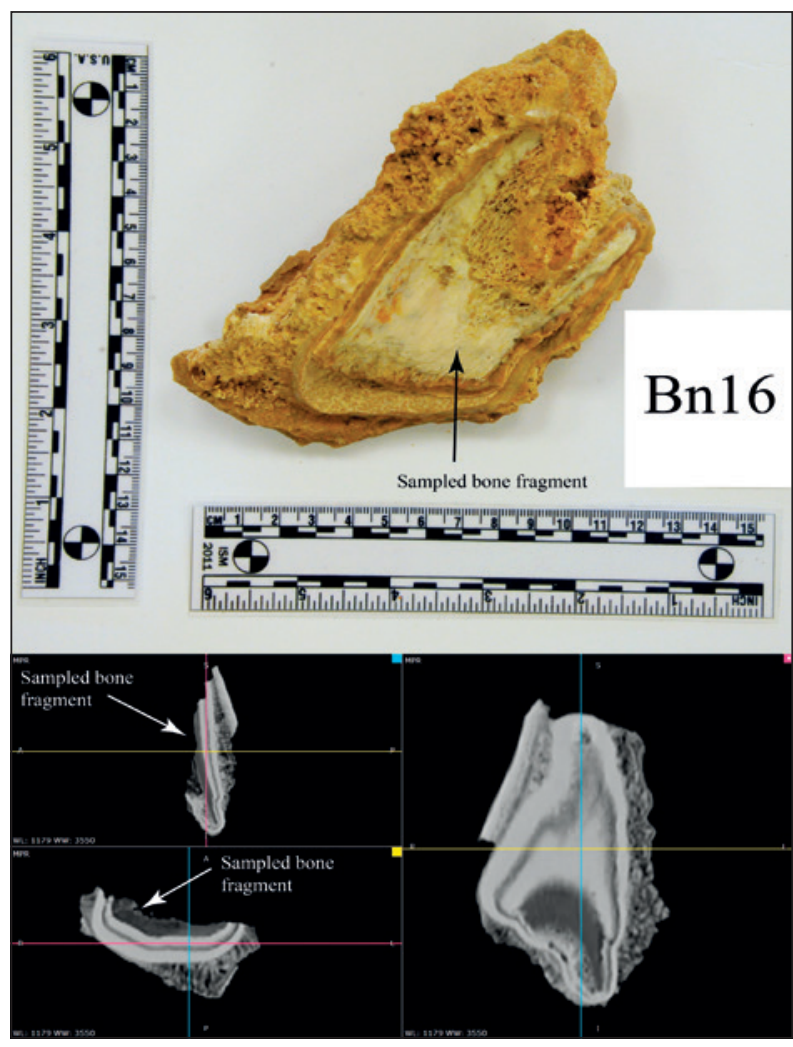

Fig. 6: Photograph and CT scans of the analysed Bn16 sample.

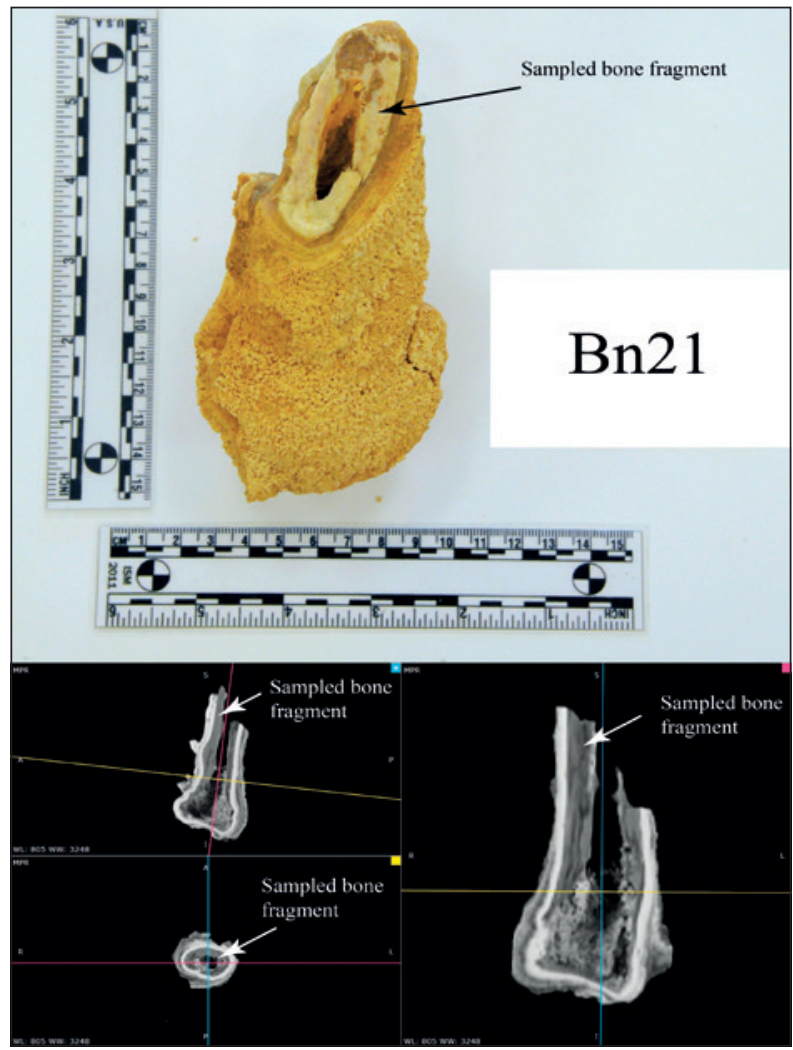

Fig. 7: Photograph and CT scans of the analysed Bn21 sample. 
samples for isotopic and dating analyses. Prior to and after each drilling, the surface was cleaned with deionized water and dried under clean air. Drilling was performed with a $1 \mathrm{~mm}$ drill in a clean environment targeting nonporous laminae. A stainless steel spatula and weighing paper were used to harvest $1.5 \mathrm{mg}$ of the drilled powder for stable isotope analysis and $3 \mathrm{mg}$ for U-Th analysis, which were transferred to clean $0.5 \mathrm{ml}$ sterile vials.

The other half of the stalagmite (including the remains of the bone fragments) was used to prepare geological thin sections ( $40-50 \mu \mathrm{m}$ thick) at the Ivan Rakovec Institute of Palaeontology ZRC-SAZU and examined using polarising Microscope Axio Scope at the Department of Archaeology, University of Ljubljana. Images of the crystal fabric were taken, using Digital Microscopy Camera Axiocam.

\section{FTIR-ATR ANALYSIS}

Powdered bone samples were analysed using a Bruker Vertex 80 equipped with diamond ATR accessory and MCT detector. The domain between $400 \mathrm{~cm}^{-1}$ and $4000 \mathrm{~cm}^{-1}$ was scanned as it corresponds to most of the organic and inorganic compounds in the bone (Buijs et al. 2004). The spectrum of each sample was collected as an average of 64 scans at a resolution of $4 \mathrm{~cm}^{-1}$. Data were analysed using OriginPro 2017 software (OriginLab Corporation) focusing on the domain between $450 \mathrm{~cm}^{-1}$ and $2000 \mathrm{~cm}^{-1}$. The baseline was subtracted, followed by the normalisation of each spectrum to the highest peak $\left(\mathrm{v}^{3} \mathrm{PO}_{4}\right.$ at $\left.\sim 1010 \mathrm{~cm}^{-1}\right)$. To determine the position of $\sim 961 \mathrm{~cm}^{-1}$, the Savitzky-Golay $2^{\text {nd }}$ derivatives with 5 points of window were performed on the domain between $800 \mathrm{~cm}^{-1}$ and $1000 \mathrm{~cm}^{-1}$.

Various parameters were acquired from the normalised spectra (Tab. 1). Additionally, spectra of all the samples were compared to modern human and sheep bone. It should be noted that, even though the human and sheep samples are modern, they were previously frozen and may deviate from the actual spectra of a fresh bone.

\section{DNA}

\section{Extraction of DNA}

Genomic DNA was obtained from $0.5 \mathrm{~g}$ of bone powder using a full demineralization protocol as described by Zupanič Pajnič (2016). In brief, bone powder was incubated in $10 \mathrm{ml}$ of $0.5 \mathrm{M}$ ethylene diamine tetra acetic acid - EDTA pH 8.3 overnight at $37^{\circ} \mathrm{C}$ for decalcification, and the precipitate was washed with sterile bi-distilled water (Sartorius-Stedim Biotech or Millipore). An extraction buffer, proteinase K and DTT were added to the precipitate and incubated for 2 hours at $56^{\circ} \mathrm{C}$. After centrifugation, the supernatant was taken to purify the DNA in a Biorobot EZ1 device (Qiagen) using the EZ1 DNA Investigator Card and EZ1 DNA Investigator Kit (Qiagen) following the manufacturer's instructions for trace protocol (Qiagen Companies 2014). In the extraction process, negative controls were included to check cleanliness of laboratory plastics and reagents. Testing of extraction negative controls and PCR negative controls was performed in parallel with bone DNA extracts to detect contamination introduced from reagents during the extraction and amplification procedure. More than one extract should be prepared from each specimen and both should yield identical DNA sequences (Pääbo et al. 2004). Therefore, DNA extraction was performed twice from sample 5 that produced DNA of suitably quality for sequencing.

\section{PCR amplification and sequencing}

Extracted DNA was used in the PCR to amplify mitochondrial gene encoding cytochrome b (cyt b) of uniden-

Tab. 1: Parameters, acquired from the normalised spectra of each sample.

\begin{tabular}{|c|c|c|c|}
\hline PARAMETER & $\sim$ PEAKS & CHARACTERISATION & REFERENCE / CALCULATION \\
\hline SF & $(560+600) / 585$ & $\begin{array}{c}\text { crystallinity, indicating crystal size and } \\
\text { order in the matrix }\end{array}$ & $\begin{array}{l}\text { (Weiner \& Bar-Yosef 1990; } \\
\quad \text { Surovell \& Stiner 2001) }\end{array}$ \\
\hline Height of $\mathrm{CO}_{3}$ peak & 711 & $\begin{array}{l}\text { incorporation of exogenous carbonates } \\
\text { into the bone from the burial environment }\end{array}$ & $\begin{array}{c}\text { (Hassan et al. 1977; Snoeck et } \\
\text { al. 2014) }\end{array}$ \\
\hline $\mathrm{C} / \mathrm{P}$ & 1415 / 1010 & carbonate relative to phosphate & $\begin{array}{c}\text { (Wright \& Schwarcz 1996; Olsen } \\
\text { et al. 2008; Thompson et al. } \\
\text { 2009) }\end{array}$ \\
\hline $\mathrm{Cl} 30 / 20$ & 1030 / 1020 & $\begin{array}{l}\text { crystallinity index (stoichiometric vs. non- } \\
\text { stoichiometric apatites) }\end{array}$ & (Lebon et al. 2010) \\
\hline $\mathrm{Aml} / \mathrm{P}$ & 1650 / 1010 & amide I relative to phosphate & $\begin{array}{c}\text { (Trueman et al. 2004; Lebon et } \\
\text { al. 2016) }\end{array}$ \\
\hline $\mathrm{Aml} / \mathrm{CO}_{3}$ & 1650 / 1415 & amide I relative to carbonate & \\
\hline API & $1540 / 600$ & relative proportion of type A carbonates & (Snoeck et al. 2014) \\
\hline BPI & 1415 / 600 & relative proportion of type B carbonates & (Snoeck et al. 2014) \\
\hline Position of 961 peak & 961 & order in the mineral lattice & (Lebon et al. 2010) \\
\hline
\end{tabular}


MATEJ LIPAR, IRENA ZUPANIČ PAJNIČ, MARKO COTMAN, JELKA ZABAVNIK PIANO, JIAN-XIN ZHAO, DEAN PEKAROVIČ \& TAMARA LESKOVAR

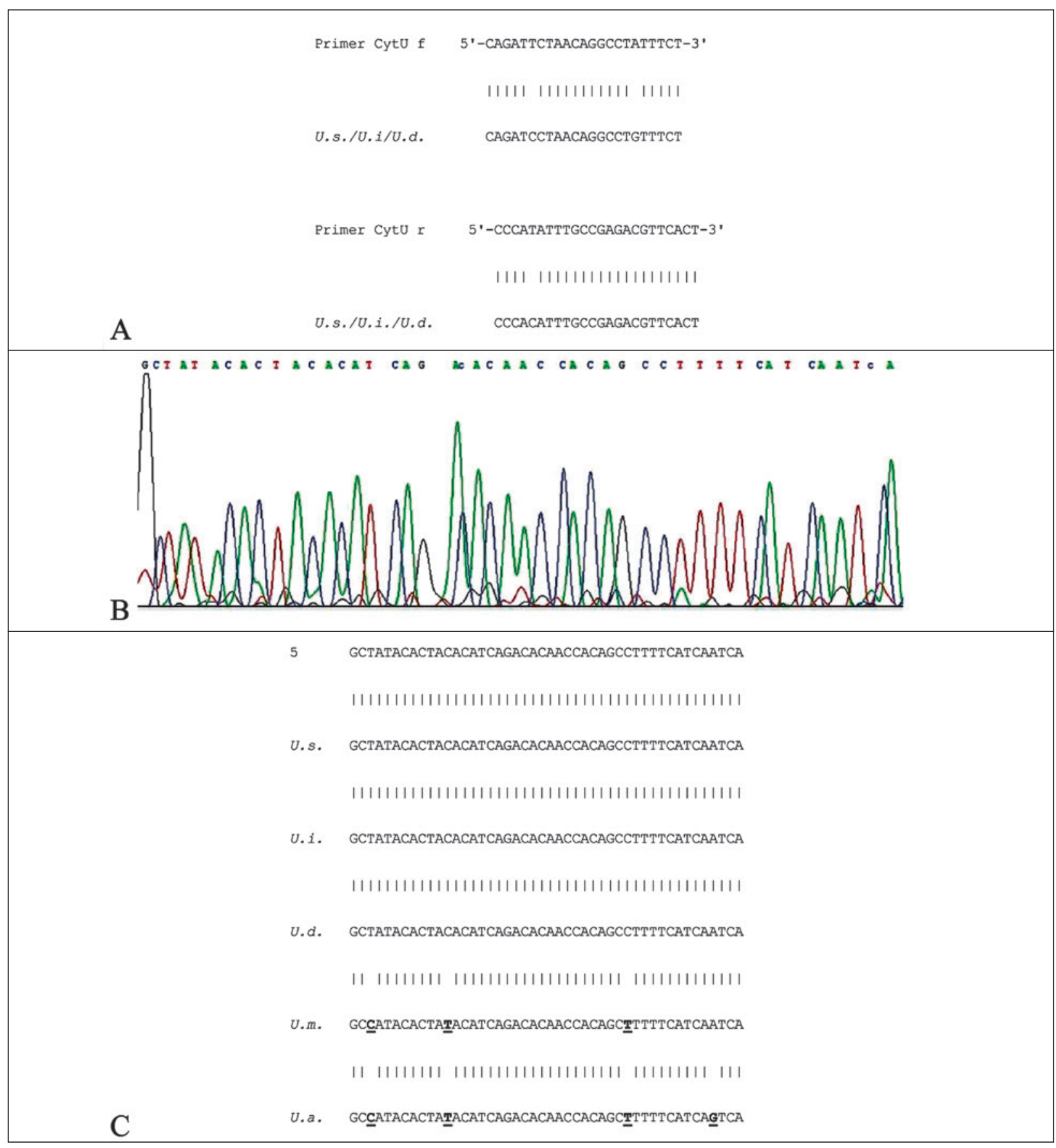

Fig. 8: Primers used for the amplification and sequencing of the DNA extracted from bone sample 5 and comparison with the sequences of species from Ursidae family.
A.) Alignment of primers designed for Cyt b gene of U. arctos to Cyt b sequences of U. spelaeus, U. ingressus and U. deningeri
B.) 46 bp long amplified sequence from DNA extracted from bone sample 5
C.) Alignment of sequences amplified from DNA extracted from bone sample 5 to different bear species:
U.s. - Ursus spelaeus (KX641337.1) (Fortes et al. 2016)
U.i. - Ursus ingressus (KX641331.1) (Fortes et al. 2016)
U.d. - Ursus deningeri (KF437625.2) (Dabney et al. 2013)
U.m. - Ursus maritimus (JX196383.1) (Miller et al. 2012)
U.a. - Ursus arctos (MF593979.1) (Benazzo et al. 2017) 
tified species with the primers designed for various species. Primers specific for Felidae, Canidae, Ursidae, Cervidae and Bovidae families were designed for amplification of short fragments (approximately 100 bp). For PCR, extracted DNA $(6 \mu \mathrm{L})$ was added to $6 \mu \mathrm{L}$ of Platinum ${ }^{\circledast}$ Multiplex PCR Master Mix and $0.5 \mu \mathrm{l}$ of each forward and reverse primers. For the negative control reactions, the final reaction volume was adjusted to $12 \mu \mathrm{L}$ with PCR-grade water. Amplification of the specific region was performed by SimplyAmp Thermal Cycler (Thermo Fisher Scientific) under the following conditions: activation of Platinum ${ }^{\circledR}$ Multiplex PCR Master Mix for 11 min at $95^{\circ} \mathrm{C}, 35$ cycles of denaturation $\left(20 \mathrm{~s}\right.$ at $\left.94^{\circ} \mathrm{C}\right)$, annealing $\left(10 \mathrm{~s}\right.$ at $\left.56^{\circ} \mathrm{C}\right)$ and extending $\left(30 \mathrm{~s}\right.$ at $\left.72{ }^{\circ} \mathrm{C}\right)$. After the last cycle, final extension was made for $2 \mathrm{~min}$ at 72 ${ }^{\circ} \mathrm{C}$. Successful amplification was obtained when using primers specific for Ursidae (shown in Fig. 8). The same primers were used in Sanger sequencing (ABI Prism 310 Genetic Analyser, Applied Biosystems) to determine the nucleotide sequences of the obtained DNA fragment. This was obtained using BigDye ${ }^{\mathrm{Tm}}$ Terminator v1.1 Cycle Sequencing Kit (Applied Biosystems) according to manufacturer user guide protocol for sequencing of PCR products. Sequences were analysed by BLAST alignment (Zhang et al. 2000). Sequencing was performed at least once for all samples and repeated twice for sample 5 to confirm the obtained DNA sequences.

\section{GEOCHEMISTRY}

Three samples of the stalagmite (i.e., Bn5) and an extra sample of the associated flowstone (Bn14) were dated by the uranium-thorium (U-Th) method at the University of Queensland. Ages were corrected for non-radiogenic ${ }^{230} \mathrm{Th}$ incorporated at the time of deposition. Full details of the method are provided in Zhou et al. (2011) and Clark et al. (2014). Age errors are reported as $2 \sigma$ uncertainties.

The stable isotope laboratory at the University of Melbourne, Australia, was used to analyse stalagmite samples for both $\delta^{13} \mathrm{C}$ and $\delta^{18} \mathrm{O}$ isotopes. Analyses were performed on $\mathrm{CO}_{2}$ produced by reaction of the sample with $100 \% \mathrm{H}_{3} \mathrm{PO}_{4}$ at $70{ }^{\circ} \mathrm{C}$ using continuous-flow isotope ratio mass spectrometry (CF-IRMS), following the method previously described in Drysdale et al. (2009) and employing an AP2003 instrument. Results are reported using the standard $\delta$ notation (per mille $\%$ ) relative to the Vienna PeeDee Belemnite (VPDB scale). The uncertainty on the NEW1 working standard was $0.05 \%$ for $\delta^{13} \mathrm{C}$ and $0.07 \%$ for $\delta^{18} \mathrm{O}$.

\section{RESULTS AND DISCUSSION}

\begin{abstract}
BONE FRAGMENTS PRESERVATION
The thin sections under the transmitted and cross polarised light revealed that calcite crystals surrounded and infiltrated the bone, most obviously in the outer parts of the compact bone and in the pores between trabeculae (Fig. 9), indicating that the microstructure of the bone is altered. There is no visible outer circumferential layer, which might be due to damaged periosteal area. Organised fibrolamellar complex with parallel fibered bone is also missing. Recognisable are lamellae, mainly forming the endosteal part, while mid part appears to be formed by compacted coarse cancellous bone. Locally, loose Haversian bone can be seen (for comparison see Veitschegger et al. (2018) and McFarlin et al. (2016)). The use of polarised light indicates diagenetically altered bone seen in bright, cloudy regions and brilliantly white calcite infiltrations. Also, birefringence is nearly lost, only occasionally pockets of light and dark structure and "Maltese cross" patterns of the osteons are present, indicating structural preservation (Turner-Walker \& Mays 2008). If the orientation of hydroxylapatite crystallites is preserved, birefringence can persist even after complete
\end{abstract}

loss of collagen (Gillette 1994; Turner-Walker \& Mays 2008).

FTIR-ATR spectroscopy shows various degree of bone preservation depending on different fragments, some exhibiting a presence of amides, indicating a possible presence of collagen (Tab. 2, Figs. 10-11). Samples lost some carbonates, mainly type A carbonates, but also have exogenous carbonates incorporated into the lattice. There is a clear correlation between loss of type A carbonates (decrease in carbonate ions with a reduction in type A (OH-substituting) carbonates (API) and increase in splitting factor (SF)). The correlation between changes in type $\mathrm{B}\left(\mathrm{PO}_{4}\right.$-substituting) carbonates (BPI) and $\mathrm{SF}$ are not clear, which is probably due to the incorporation of exogenous carbonates into the bones from the burial environment. The most obvious outlier is the $\mathrm{Bn} 15$ sample, which might be due to the simultaneous incorporation of exogenous carbonates with limited loss of structural carbonates, yet the complete loss of organic matter. Sample Bn16 has high crystallinity index (CI 30/20 ratio) and a significant shift of $\mathrm{PO}_{4}$ peak towards higher frequencies. This probably indicates more order in the lattice due to 
recrystallisation processes in the sample, including loss of organic matter and incorporation of carbonates from the burial environment. Bn21 sample has the highest SF, lowest API, BPI, CI 30/20 ratio and highest shift of $\mathrm{PO}_{4}$ peak. This sample lost most of the structural carbonates, while the incorporation of the exogenous carbonates was limited, leading to significant growth of the crystals and ordering of the lattice.
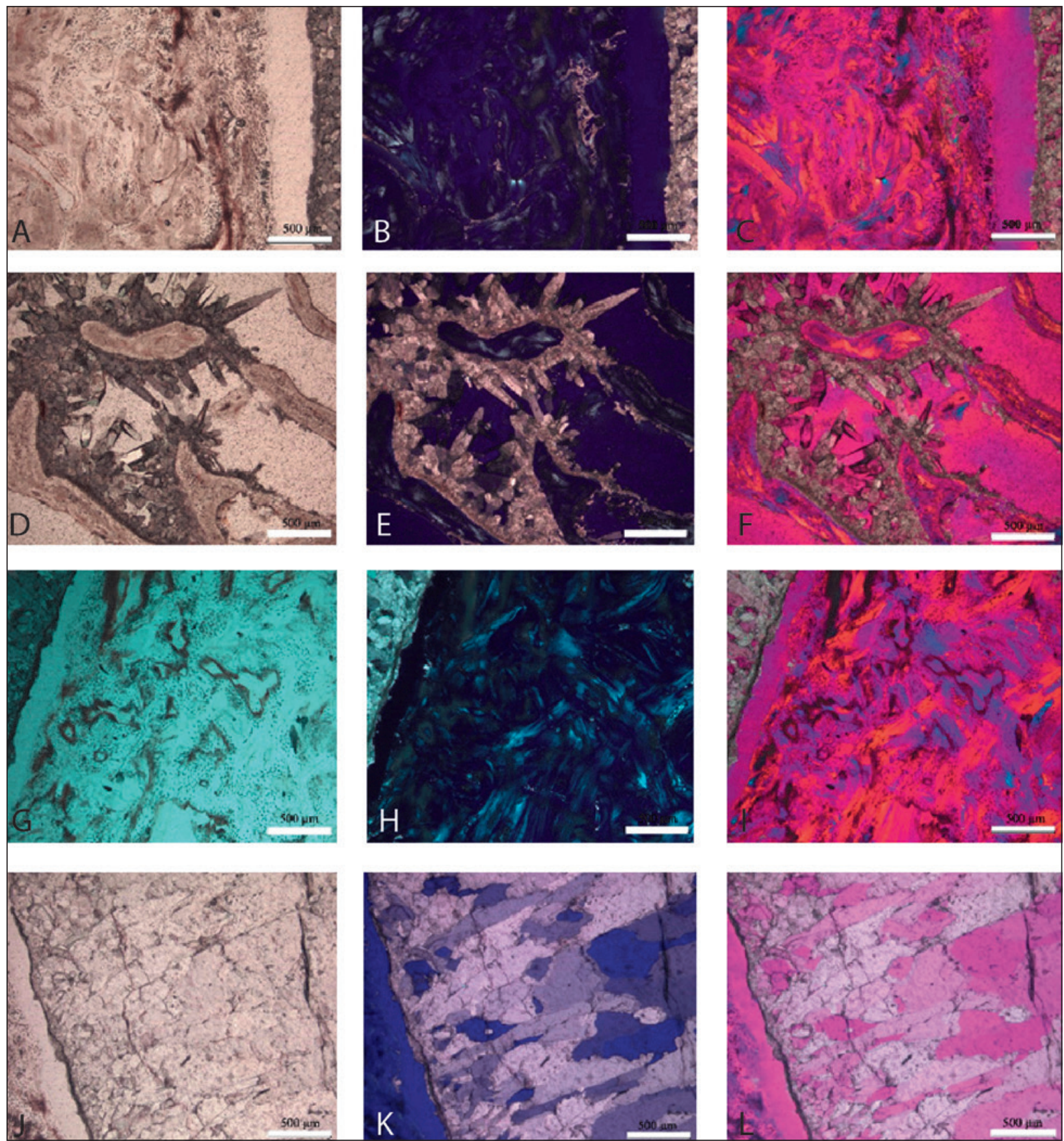

Fig. 9: Thin section images of the bone (Bn5) and calcite crystals within the speleothem under transmitted light (left), polarised light (middle) and with the use of lambda plate - 50x magnification. A, B \& C: The periosteal area of the bone is surrounded by calcite crystals that also infiltrate the bone (scale bar represents $500 \mu \mathrm{m}$ ). D, E\& F: The pores between trabeculae are filled with calcite crystals (scale bar represents $500 \mu \mathrm{m})$. G, $\mathrm{H} \& \mathrm{I}$ : Bone microstructure is partially preserved as osteons, lacnae and lamellae are still recognisable, and birefringence is seen with the presence of dark and light areas (scale bar represents $500 \mu \mathrm{m}$ ). J, K \& L: A contact between the bone (left lower corner) and columnar fabrics of speleothem with progressively larger elongated calcite crystals (right side of the picture). 
Tab. 2: Calculated parameters and estimated mineral crystal size and the amount (\%) of organic matter for each sample.

\begin{tabular}{|c|c|c|c|c|c|c|c|c|c|c|c|}
\hline SAMPLE & SF & $\mathrm{CO}_{3}$ & $\mathrm{Cl}$ & $C / P$ & $\mathrm{Aml} / \mathrm{P}$ & $\mathrm{Aml} / \mathrm{CO}_{3}$ & API & BPI & $\mathrm{PO}_{4}$ & $\begin{array}{l}\text { Crystal size } \\
\text { (nm) }\end{array}$ & $\begin{array}{c}\text { Organics } \\
\text { WT \% }\end{array}$ \\
\hline $\begin{array}{l}\text { MODERN } \\
\text { HUMAN }\end{array}$ & 3.5 & 0 & 0.84 & 0.34 & 0.28 & 0.83 & 0.64 & 0.99 & 958.5 & 55.94 & 18.48 \\
\hline $\begin{array}{l}\text { MODERN } \\
\text { SHEEP }\end{array}$ & 3.6 & 0 & 0.86 & 0.19 & 0.17 & 0.91 & 0.47 & 0.79 & 958.8 & 57.88 & 12.82 \\
\hline Bn5 & 4.1 & 0.02 & 0.8 & 0.28 & 0.09 & 0.31 & 0.17 & 0.85 & 958.5 & 67.42 & 5.11 \\
\hline Bn14 & 4.1 & 0.01 & 0.77 & 0.22 & 0.05 & 0.24 & 0.12 & 0.72 & 958.5 & 68.66 & 0.08 \\
\hline $\mathrm{Bn} 15$ & 4.0 & 0.05 & 0.82 & 0.32 & 0.05 & 0.17 & 0.15 & 1.26 & 960.6 & 65.8 & 0.22 \\
\hline Bn16 & 4.1 & 0.07 & 0.87 & 0.28 & 0.09 & 0.31 & 0.17 & 0.85 & 961.8 & 68.24 & 5.11 \\
\hline $\mathrm{Bn} 21$ & 5.3 & 0.02 & 0.76 & 0.26 & 0.04 & 0.14 & 0.07 & 0.68 & 961.8 & 94.08 & -4.26 \\
\hline
\end{tabular}

In general, the organic matter (collagen) is poorly preserved or not preserved at all. The amount of organic matter in the samples is inversely correlated to the SF and thus crystal growth. The best-preserved samples with possible organic matter were Bn5 and Bn16. Combining all the factors, the least diagenetically altered sample was $\mathrm{Bn} 5$, which was also the most appropriate for further DNA analysis, while the most severely altered sample was $\mathrm{Bn} 21$. This indicates variability in the degree of bone fragments preservation in the Postojna Cave and shows the advantage of FTIR-ATR analysis conducted prior to DNA extraction attempt; as Bn5 sample was the bestpreserved sample and subsequently with the thickest and least porous cover of flowstone, it demonstrates the type of perspective samples for future sampling.

\section{SPECIES IDENTIFICATION (DNA SEQUENCES)}

Various primers were used to amplify short regions of the mtDNA. However, successful amplification of a 94 bp fragment of mtDNA in PCR screening was obtained only from bone sample Bn5 (in accordance with the FTIR-ATR results discussed in previous section). The same sequences were obtained also with repetition of DNA extraction, amplification and sequencing. Nucleotide sequencing produced a $70 \mathrm{bp}$ long read, from these 24 bp corresponded to the aligned primer sequences, 46 bp were amplified from the ancient DNA. BLAST alignment showed that the sequences correspond completely to mitochondrial $c y t b$ of Ursus deningeri, Ursus spelaeus and Ursus ingressus. No amplification was obtained in the PCR reactions with primers specific for larger fragments

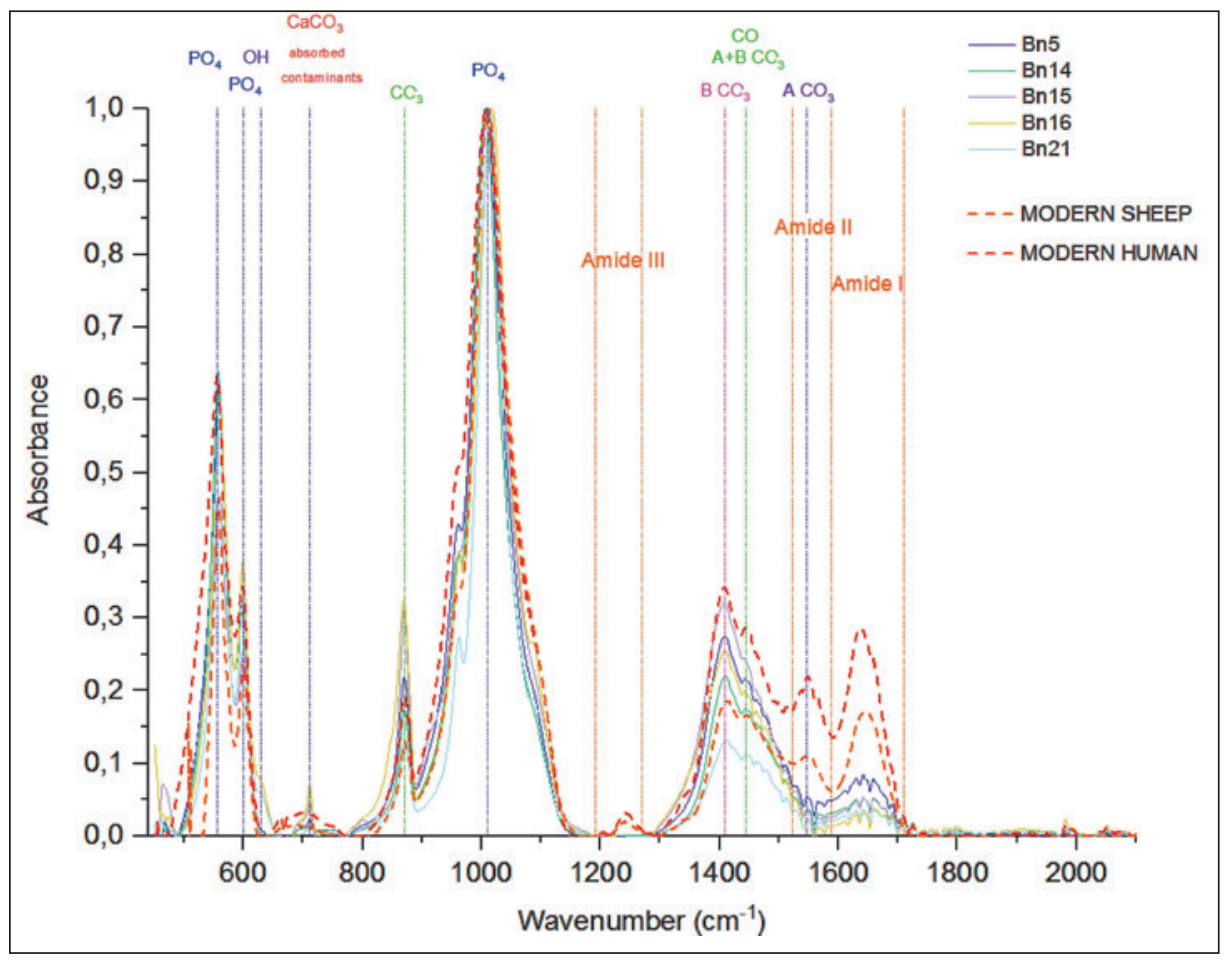

Fig. 10: FTIR-ATR obtained and normalised spectra for each of the analysed samples compared to modern sheep and human bone. Changes in stalagmite bone samples are present in the peaks representing carbonates, phosphates and amides (collagen). There is an increase in $\mathrm{CaCO}_{3}$ at $710 \mathrm{~cm}^{-1}$ and $\mathrm{CO}_{3}$ at $860 \mathrm{~cm}^{-1}, \mathrm{PO}_{4}$ peak at $1010 \mathrm{~cm}^{-1}$ is narrower with better pronounced step at $960 \mathrm{~cm}^{-1}$, amide III peak is completely gone and a significant loss of amide II and I peaks occurred. The latter is best preserved in the Bn5 sample. 


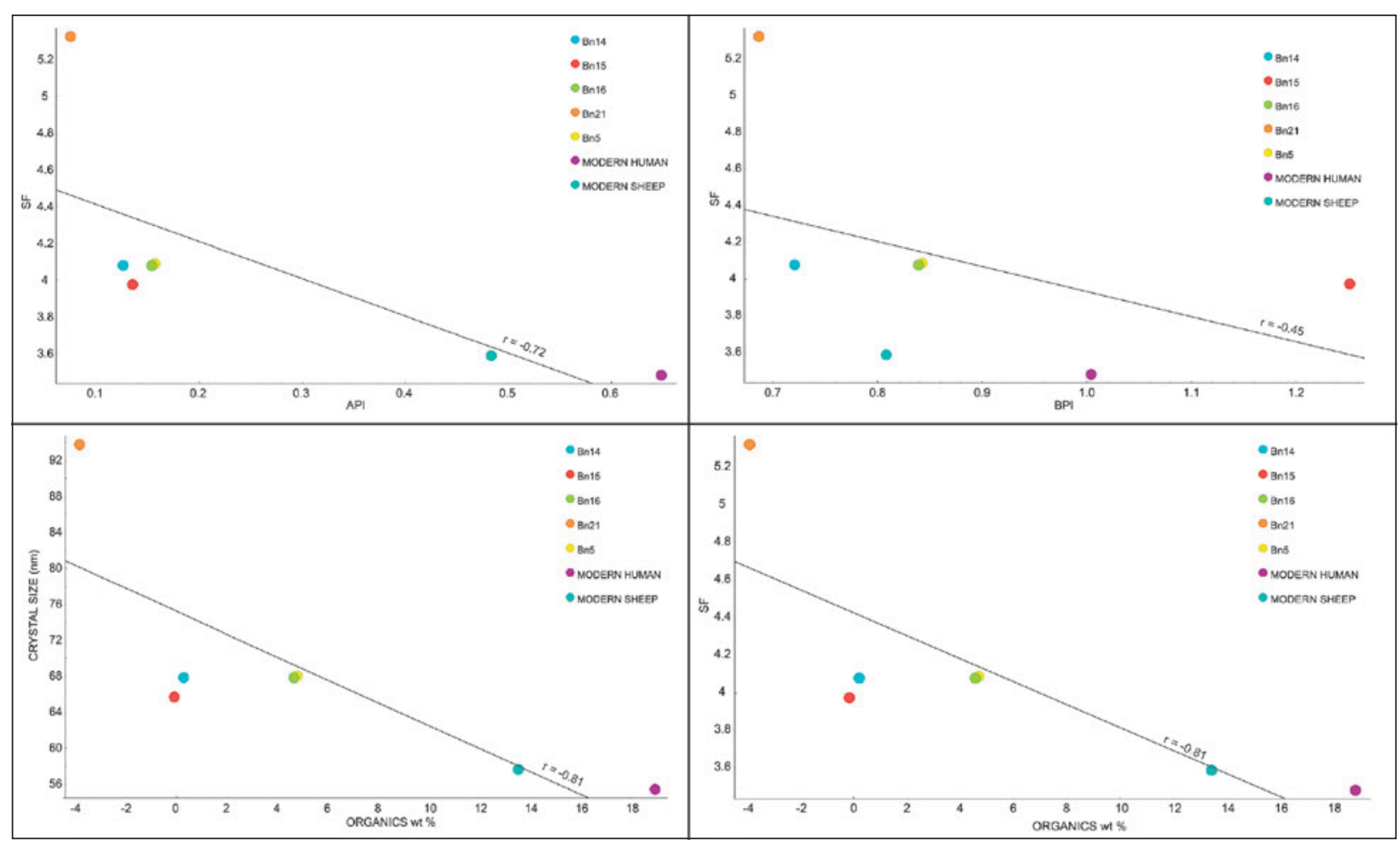

Fig. 11: Strong negative linear correlation between SF and API parameters (A); moderate negative linear correlation between SF and BPI parameter (B); strong negative linear correlation between crystal size and preserved organic matter (C); strong negative linear correlation between $S F$ parameter and preserved organic matter (D).

of $c y t b$, possibly due to DNA degradation processes (Allentoft et al. 2012) for other species or in samples serving as negative controls. Sequence of DNA extracted from the sample Bn5 is shown in Fig. 8.

The primers used in the study were designed to amplify short fragments of mtDNA of various species. In all negative control reactions no PCR product or DNA sequences were obtained. When DNA sequences identical to some species in Ursidae family were obtained from the bone sample Bn5, the authenticity was confirmed by the additional DNA extraction from this sample; PCR amplification and sequencing of the obtained PCR product showed exactly the same DNA sequence as in the first DNA extraction, therefore we could conclude that the DNA present in the sample Bn5 is not due to contamination.

Nucleotide sequences of the obtained fragment of mtDNA correspond to the mtDNA of Ursus deningeri, a cave bear of the Middle Pleistocene which transitioned into Ursus spelaeus sensu lato in the Late Pleistocene, and its descendents Ursus spelaeus sensu stricto and Ursus ingressus which probably disappeared from the Alps and adjacent areas before $28 \mathrm{ka}$ (Pacher \& Stuart 2009; Dabney et al. 2013). These cave bear species/subspecies are in complete alignment in the region of $c y t b$ gene amplified in our study. The nucleotide sequences of the corresponding DNA fragment of the brown bear (Ursus arc- tos) (Fortes et al. 2016), which at present lives in Europe, differs by $8.7 \%$ ( 4 nucleotides from 46 ).

It is known that cave bears frequented Postojna Cave (Brodar 1966), however the species had not yet been confirmed by genetic studies. The other genetic studies on cave bear in Slovenia (Potočka zijalka cave, Ajdovska jama cave) were reported by Hofreiter \& Pacher (2004), Rabeder et al. (2004b) and Rabeder et al. (2011). Therefore, further studies are needed to obtain more data on mtDNA sequences from the bone in the stalagmite from Postojna Cave in order to determine which cave bear species was living in the cave in the period around $55 \mathrm{ka}$.

\section{BONE THANATOCOENOSIS AND ENVIRONMENTAL CONDITIONS}

The stalagmite associated with the bone (Bn5) has a base diameter of around $130 \mathrm{~mm}$ and a growth axis length of $165 \mathrm{~mm}$ (Fig. 12). It is light brown to beige in colour with multiple hiatuses. In addition, the stalagmite has large solutional cavities throughout the entire cross-section. This defines the stalagmite as not reliable for high-resolution palaeoclimatic analyses. Consequently, only three dates were extracted from the stalagmite in order to get an approximate timing of speleothem deposition, and only a low-resolution $\delta^{13} \mathrm{C}$ and $\delta^{18} \mathrm{O}$ isotopic analysis was performed. 
Tab. 3: U/Th analysis data. Two laboratory standards included: SRM-960 U is a metal standard manufactured during the World War II ( 1936), YB-1 is an ANU speleothem standard with an age of $30.2 \pm 0.6 \mathrm{ka}$. The number following the sample "Bn5_" represents distance from the top in $\mathrm{mm}$.

\begin{tabular}{|c|c|c|c|c|c|c|c|c|c|}
\hline Sample Name & $\begin{array}{l}\text { Sample } \\
\text { wt. (g) }\end{array}$ & U (ppm) & $\pm 2 \mathrm{~s}$ & $\begin{array}{l}{ }^{232} \mathrm{Th} \\
\text { (ppb) }\end{array}$ & $\pm 2 \mathrm{~s}$ & $\begin{array}{l}\left({ }^{230} \mathrm{Th} /\right. \\
\left.{ }^{232} \mathrm{Th}\right)\end{array}$ & $\pm 2 \mathrm{~s}$ & $\left({ }^{230} \mathrm{Th} /{ }^{238} \mathrm{U}\right)$ & $\pm 2 \mathrm{~s}$ \\
\hline Bn5_162 & 0.10702 & 0.07499 & 0.00003 & 8.891 & 0.012 & 12.716 & 0.061 & 0.4969 & 0.0023 \\
\hline Bn5_94 & 0.10382 & 0.10489 & 0.00003 & 0.696 & 0.001 & 207.47 & 0.96 & 0.4539 & 0.0020 \\
\hline Bn5_15 & 0.09760 & 0.10633 & 0.00003 & 4.079 & 0.006 & 32.57 & 0.15 & 0.4118 & 0.0018 \\
\hline Bn14 & 0.10204 & 0.12728 & 0.00007 & 6.123 & 0.008 & 31.90 & 0.12 & 0.5058 & 0.0018 \\
\hline SRM-960 standard & 0.10570 & 5.5396 & 0.0046 & 0.01 & 0.000 & 1485 & 28 & 0.00071 & 0.00001 \\
\hline YB-1 speleothem std & 0.10214 & 0.1253 & 0.0000 & 0.49 & 0.001 & 339.8 & 1.2 & 0.4343 & 0.0015 \\
\hline & $\left({ }^{234} U /{ }^{238} U\right)$ & $\pm 2 \mathrm{~s}$ & $\begin{array}{l}\text { Uncorr. } \\
\text { age (ka) }\end{array}$ & $\pm 2 \mathrm{~s}$ & $\begin{array}{l}\text { Corr. age } \\
\text { (ka) }\end{array}$ & $\pm 2 \mathrm{~s}$ & $\begin{array}{l}\text { Corr. initial } \\
\left({ }^{234} U /{ }^{238} U\right)\end{array}$ & $\pm 2 \mathrm{~s}$ & \\
\hline Bn5_162 & 1.2154 & 0.0015 & 56.39 & 0.35 & 53.54 & 1.29 & 1.2589 & 0.0046 & \\
\hline Bn5_94 & 1.2724 & 0.0015 & 47.36 & 0.26 & 47.21 & 0.27 & 1.3118 & 0.0017 & \\
\hline Bn5_15 & 1.2237 & 0.0011 & 44.19 & 0.24 & 43.28 & 0.47 & 1.2555 & 0.0019 & \\
\hline Bn14 & 1.2312 & 0.0012 & 56.69 & 0.27 & 55.56 & 0.55 & 1.2741 & 0.0023 & \\
\hline SRM-960 standard & 0.9636 & 0.0007 & 0.0805 & 0.0009 & 0.0805 & 0.0009 & 0.9636 & 0.0007 & \\
\hline YB-1 speleothem std & 1.7492 & 0.0013 & 30.53 & 0.12 & 30.46 & 0.12 & 1.8174 & 0.0014 & \\
\hline
\end{tabular}

Tab. 4: $\delta^{13} \mathrm{C}$ and $\delta^{18} \mathrm{O}$ stable isotope ratios. The number following the sample "Bn5_" represents distance from the top in $\mathrm{mm}$.

\begin{tabular}{|c|c|c|c|c|c|}
\hline Stalagmite Sample No. & $\delta^{13} \mathrm{C}(\%)$ & $\delta^{18} \mathrm{O}(\% \circ)$ & Stalagmite Sample No. & $\delta^{13} \mathrm{C}(\%)$ & $\delta^{18} \mathrm{O}(\%)$ \\
\hline Bn5_1 & -5.33 & -6.34 & Bn5_81 & -7.13 & -6.79 \\
\hline Bn5_5 & -4.35 & -5.76 & Bn5_93 & -7.20 & -6.63 \\
\hline Bn5_7 & -4.39 & -6.00 & Bn5_101 & -6.87 & -6.38 \\
\hline Bn5_15 & -6.12 & -6.57 & Bn5_107 & -7.80 & -7.40 \\
\hline Bn5_24 & -7.69 & -7.17 & Bn5_112 & -8.23 & -7.41 \\
\hline Bn5_29 & -7.23 & -6.57 & Bn5_119 & -7.07 & -6.61 \\
\hline Bn5_36 & -7.67 & -6.82 & Bn5_127 & -9.02 & -7.41 \\
\hline Bn5_45 & -7.78 & -6.88 & Bn5_134 & -8.02 & -7.15 \\
\hline Bn5_51 & -7.79 & -7.05 & Bn5_139 & -7.78 & -7.28 \\
\hline Bn5_62 & -7.39 & -7.02 & Bn5_149 & -6.72 & -7.09 \\
\hline Bn5_68 & -6.49 & -6.73 & Bn5_156 & -7.24 & -7.17 \\
\hline Bn5_76 & -6.79 & -6.79 & Bn5_163 & -4.72 & -6.47 \\
\hline
\end{tabular}

Three samples from the bottom (next to the bone fragment), middle and top part of the stalagmite yielded ages of $53.54 \pm 1.29 \mathrm{ka}, 47.21 \pm 0.27 \mathrm{ka}$ and $43.28 \pm 0.47$ ka, respectively (see Tab. 3 and Fig. 13). The additional fourth sample was measured on a flowstone coating close to the bone fragment (Bn14) yielding an age of $55.56 \pm$ $0.55 \mathrm{ka}$. The oxygen isotope ratios vary from $-7.41 \%$ to $-5.76 \%$, and carbon isotope ratios vary from $-9.02 \%$ to $-4.35 \%$ (See Tab. 4).

The growth period of the stalagmite during the last glacial period $(53.5-43.3 \mathrm{ka})$ correlates with one of the warmer phases of the Dansgaard-Oeschger events (Genty et al. 2003; Van Meerbeeck et al. 2009) during marine isotope stage (MIS) 3. It follows the general hiatus of speleothem growth during the cold stadial of MIS 4, and is later constrained by the cold stadial of MIS 2 (the Last Glacial Maximum; also reported by Gospodarič (1981)), and thus reflects a relatively favourable climate for stalagmite growth (slightly warmer climate than the glacial extremes on either side).

Furthermore, as the bones are embedded in the early MIS 3 flowstone/stalagmite, it indicates they were deposited there earlier (most probably in MIS 4 or very early in MIS 3 just before the flowstone deposition). This is in accordance with Brodar (1966) discussion that bone thanatocoenosis occurred in the early stage of the 
Würm glaciation (i.e., MIS 4), but contradicts with his assumption that flowstone coatings is of the Holocene age. Our data also correlates with a number of MIS 3 European cave bear sites, including Slovenia, summarised in Robu (2016) and references therein, where the dating methods are primarily focused on the radiocarbon technique of the bone itself. In addition, U-Th dating (alongside radiocarbon dating) of flowstone associated with cave bear bones was carried out in Križna Jama Cave, Slovenia, where dates indicate two different ages of cave bear thanatocoenosis: those above flowstone crusts were dated to ca. from $44.8+1.8 /-1.4$ to $46.7+2.4 /-1.8 \mathrm{ka} \mathrm{BP}$ by radiocarbon dating (Rabeder \& Withalm 2001), whilst those included in speleothem layers and clay interbeds were older than $94 \mathrm{ka}$ (U-Th date) (Bosák et al. 2012). Whilst radiocarbon dates around $46 \mathrm{ka}$ are doubtful due to the method detection limit, they are contemporaneous to the bones within this study.

Regarding the Postojna Cave, the other absolute flowstone dates that constrain a cave bear skull found close to the entrance are between the late MIS 3 and midMIS 5 (ca. 90 - $40 \mathrm{ka}$ ) (Ferk et al. 2019). In both cases, these ages only implicate the limit to when the remnants of bones were transported to the cave. Cave bears lived past MIS 3 (up to ca. $20 \mathrm{ka} \mathrm{BP}$ ) according to other studies (Rabeder et al. 2004a; Pacher \& Stuart 2009).

The annual temperature variation in the section of Čarobni Vrt passage where the stalagmite was collected varies between $9.15^{\circ} \mathrm{C}-9.23{ }^{\circ} \mathrm{C}\left(\Delta 0.08^{\circ}\right.$; March $2018-$ March 2020). This represents one of the passages in the Postojna Cave with the lowest annual temperature amplitude (Šebela \& Turk 2011a; Šebela \& Turk 2011b; Mandić 2013) and therefore one of the most suitable ones for using stalagmite geochemical proxies as palaeoenvironmental archives. The positive correlation of $\delta^{18} \mathrm{O}$ and $\delta^{13} \mathrm{C}$ values is strong, which may be an evidence of deposition under non-equilibrium conditions (Goede 1998), or an indicator of climatic control on both of $\delta^{18} \mathrm{O}$ and $\delta^{13} \mathrm{C}$ values (Dorale et al. 1998; Genty et al. 2003). However, solutional cavities throughout the stalagmite are too widespread and discouraged the high-resolution sampling of $\delta^{18} \mathrm{O}$ and $\delta^{13} \mathrm{C}$ isotopes. In addition, as the cavities are likely post-depositional (i.e., diagenetic porosity) and as the process could be enhanced or triggered by bacterial activity (Shtober-Zisu et al. 2014), there is a possibility of recrystallization.

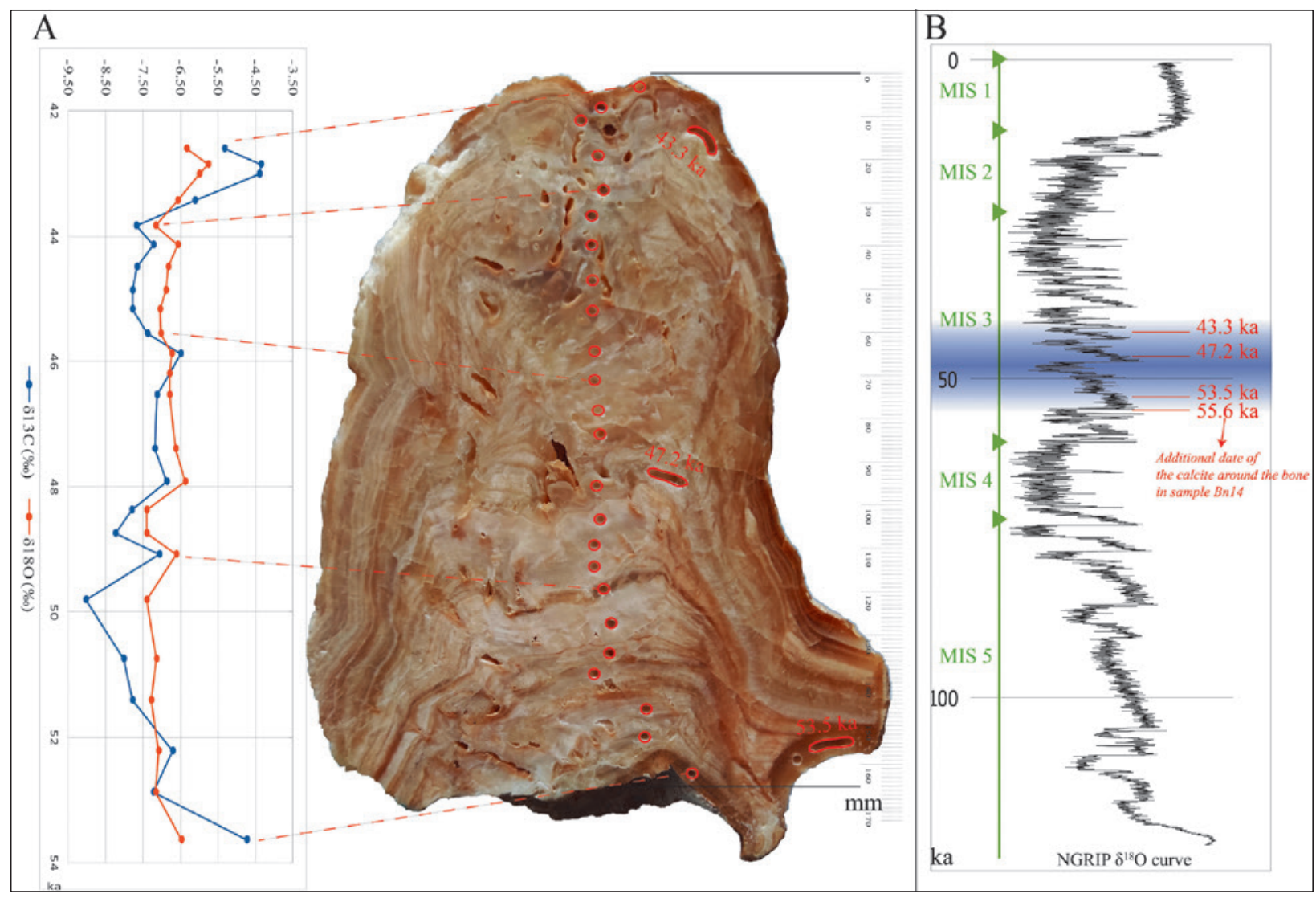

Fig. 12: Stalagmite sample with (A) carbon and oxygen isotopes following modelled U-Th ages (see Fig. 13), and (B) the oxygen isotope curve based on North Greenland Ice Core Project Oxygen Isotope Data (NGRIP) (North Greenland Ice Core Project members 2004). 
Assuming the same amount of present-day rainfall in the past, the palaeofloods were favoured in colder time intervals with intensive weathering and scarcer vegetation (Ferk 2016). Consequently, glacial extremes (e.g., MIS 4) were most probably characterised by palaeofloods, which could have been responsible also for the bone transport into the studied section of the cave. During the warmer phases of MIS 3, the palaeofloods ceased or became limited, which made the caving environment more suitable for flowstone (and stalagmite) deposition. Relatively scarcer vegetation during MIS 3 (compared to the present one) could be reflected in $\delta^{13} \mathrm{C}$ isotopic val- ues. When compared to the carbon values in modern flowstone from the Postojna Cave $(\sim-11.6 \%$ ) (Ferk et al. 2019), the ones measured in the stalagmite within this study are considerable heavier $(-9.02 \%$ o to $-4.35 \%$ ) (see Tab. 4). This suggests a reduced plant activity above the cave or a higher proportion of plants adapted to drought (Gillies 2011), most likely the steppe-like vegetation, presumed to be typical for this part of Europe during the Pleistocene (Gams 1998).

On the other hand, $\delta^{18} \mathrm{O}$ isotopes most likely show the variation in the amount of moisture (lighter isotopes would indicate wetter conditions) as also reported by

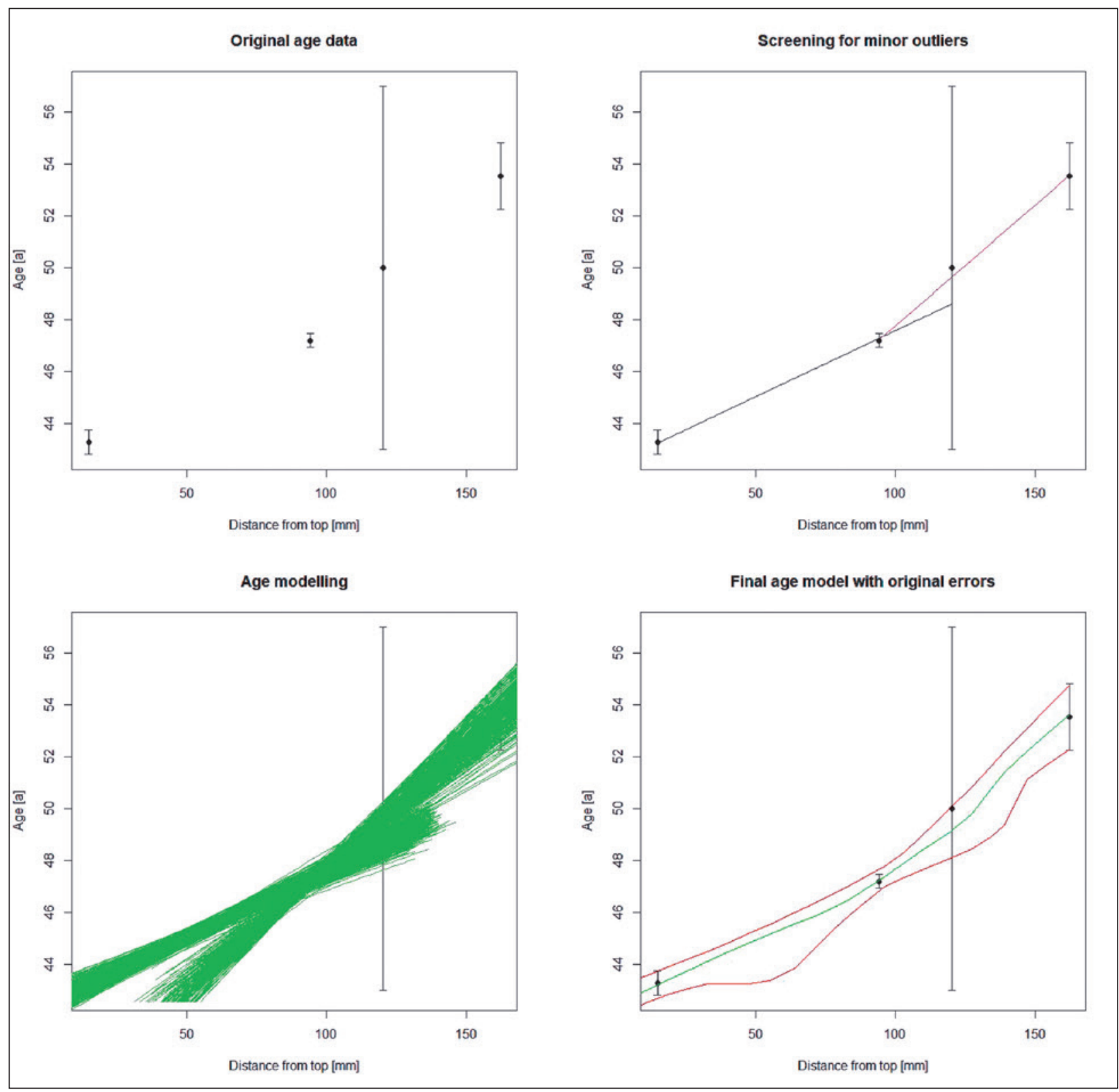

Fig. 13: Age-depth model of Scholz \& Hoffmann (2011) using StalAge algorithm. Note that one additional virtual age with a very large error bar was added for the algorithm to work (i.e., the age does not provide additional information). 
Lončar et al. (2017), because when applying the difference in rainfall $\delta^{18} \mathrm{O}$ during a temperature change in central and southwestern Slovenia $\left(0.19-0.29 \% /{ }^{\circ} \mathrm{C}\right)$ (Vreča et al. 2008, 2011, 2014, 2015; Vreča \& Malenšek 2016), and the calcite/water fractionation at the mean annual temperature of the cave $\left(\sim-0.25 /{ }^{\circ} \mathrm{C}\right.$ (O'Neil et al. 1969)) the net difference is too small for stalagmite $\delta^{18} \mathrm{O}$ to indicate only temperature changes, and there could be a small net positive or negative shift of oxygen isotopes of calcite. In this case, the $\delta^{13} \mathrm{C}$ variation which can reflect the changes in the relative abundance of two groups of plants $\mathrm{C}_{3}$ and $\mathrm{C}_{4}$, consequent soil $\mathrm{CO}_{2}$ composition and changes in vegetation productivity (Desmarchelier 2000) (and references therein), can be correlated well with changes of the $\delta^{18} \mathrm{O}$ (wetter conditions would indicate greater vegetation productivity).

\section{CONCLUSION}

Five fragments of animal bone samples associated with flowstone coatings and stalagmite were collected in Čarobni Vrt passage in Postojna Cave, Slovenia. As noted on CT X-ray scans the bones preserved a distinctive outer cortical and inner trabecular parts, so further analyses were conducted to determine the preservation of bone fragments, the animal species identification, and the time of thanatocoenosis together with environmental conditions at that time.

Based on the FTIR-ATR results, all the samples were highly altered. However, best preserved sample was Bn5. The mineral matrix of the sample is one of the least altered, when compared to other samples in the study, and has best preserved organic matter. This can also be seen through histology, as in this sample pockets with preserved birefringence and Maltese cross can be detected, indicating preservation of the original bone matrix. As sample Bn5 was also the only one that produced DNA of suitable quality for sequencing, our results indicate that FTIR-ATR obtained spectra, especially in combination with histological analysis, can be used as a pre-screening method for DNA preservation.

Nucleotide sequences of the obtained fragment of mtDNA correspond to the mtDNA of Ursus deningeri, which also represents the first genetic identification of the extinct mammal species from Postojna Cave and offers feasible grounds for further genetic analyses.

Bone thanatocoenosis occurred prior to $55 \mathrm{ka}$, in early MIS 3 or MIS 4, which was determined by U-Th dates of the first layer of flowstone coating the bone. The time of MIS 4 was most probably characterised by palaeofloods, followed by the flowstone deposition since around $55 \mathrm{ka}$ (MIS 3) that continued for around $10 \mathrm{ka}$ and correlates with one of the warmer phases of the Dansgaard-Oeschger events. The stable isotopes of the stalagmite suggest a reduced plant activity above the cave or a higher proportion of plants adapted to drought, most likely the steppe-like vegetation, but the stalagmites at this part of the cave are generally not suitable for highresolution palaeoclimatic interpretation due to high porosity and recrystallisation.

\section{ACKNOWLEDGEMENTS}

We thank Jožef Jerič (Kamnoseštvo Kamen Jerič s.p.) for stalagmite cutting and polishing, Kata Cvetko-Barić for preparing the geological thin sections, Clinical Radiology Institute (UMC Ljubljana) for the permissions to access to the CT modality, and Russell N. Drysdale for performing isotopic analyses. We also thank Postojnska jama d.d. and the Ministry of Environment and Spatial Planning of Slovenia for the permissions to access the cave and collect samples. Part of the field work was also assisted by Marjan Vilhar, who tragically passed away earlier in 2020.
The research was financially supported by the European Regional Development Fund: European Union \& Republic of Slovenia, Ministry of Education, Science and Sport (2017-2020; research programme OP20.01261), by the Slovenian Research Agency research core funding Geography of Slovenia (P6-0101) and Archaeology (P60247), Infrastructure Programme (I0-0031), and by the Slovenian Research Agency (project "Determination of the most appropriate skeletal elements for molecular genetic identification of aged human remains" (J3-8214)). 


\section{AUTHOR CONTRIBUTIONS}

M.L. designed the research, led the study, conducted field work and early laboratory analyses including thin section analyses, wrote the geochemistry and palaeoenvironmental part of the paper, and the final draft of the paper. I.Z.P., M.C., J.Z.P. conducted DNA laboratory analyses, wrote DNA part of the paper, reviewed the paper. J.Z. conducted U-Th analyses, and reviewed the paper. D.P. conducted computed tomography analyses and wrote the methods part for this analysis. T.L. conducted FTIR-ATR analyses and bone thin section analysis, wrote bonestructure and bone-chemistry part of the paper, and reviewed the paper.

\section{REFERENCES}

Allentoft, M.E., Collins, M., Harker, D., Haile, J., Oskam, C.L., Hale, M.L., Campos, P.F., Samaniego, J.A., Gilbert, M.T., Willerslev, E., Zhang, G., Scofield, R.P., Holdaway, R.N. \& M. Bunce, 2012: The half-life of DNA in bone: measuring decay kinetics in 158 dated fossils.- Proceedings of the Royal Society B: Biological Sciences, 279, 1748, 4724-4733. http:// dx.doi.org/10.1098/rspb.2012.1745

Amory, S., Huel, R., Bilic, A., Loreille, O. \& T.J. Parsons, 2012: Automatable full demineralization DNA extraction procedure from degraded skeletal remains. Forensic Science International Genetics, 6, 3, 398406. http://dx.doi.org/10.1016/j.fsigen.2011.08.004

Benazzo, A., Trucchi, E., Cahill, J.A., Maisano Delser, P., Mona, S., Fumagalli, M., Bunnefeld, L., Cornetti, L., Ghirotto, S., Girardi, M., Ometto, L., Panziera, A., Rota-Stabelli, O., Zanetti, E., Karamanlidis, A., Groff, C., Paule, L., Gentile, L., Vila, C., Vicario, S., Boitani, L., Orlando, L., Fuselli, S., Vernesi, C., Shapiro, B., Ciucci, P. \& G. Bertorelle, 2017: Survival and divergence in a small group: The extraordinary genomic history of the endangered Apennine brown bear stragglers.- Proceedings of the National Academy of Sciences of the United States of America, 114, 45, E9589-E9597. http://dx.doi.org/10.1073/ pnas. 1707279114

Bosák, P., Pruner, P., Zupan Hajna, N., Hercman, H., Mihevc, A. \& J. Wagner, 2012: Križna jama (SW Slovenia): Numerical-and correlated-ages from cave bear-bearing sediments.- Acta Carsologica, 39, 3, 529-549 http://dx.doi.org/10.3986/ac.v39i3.82

Brodar, S., 1966: Pleistocenski sediment in paleolitska najdišča v Postojnski jami.- Acta Carsologica, 4, 55-138.

Brodar, S., 1969: Latest Palaeolithic discoveries in the Postojna Caves.- Acta Archaeologica, 20, 141-145.

Buijs, H.L., Rochette, L. \& F. Chateauneuf, 2004: Evolution of FTIR technology as applied to chemical detection and quantification.- In: Sedlacek, A.J. et al. (eds)
Optical technologies for industrial, environmental, and biological sensing, $27^{\text {th }}-31^{\text {st }}$ October 2003, Providence, 132-142. https://doi.org/10.1117/12.516519

Buser, S., Grad, K. \& M. Pleničar, 1967: General Geological Map SFRJ 1:100.000, Postojna sheet.- Beograd.

Carracedo, A., Bär, W., Lincoln, P., Mayr, W., Morling, N., Olaisen, B., Schneider, P., Budowle, B., Brinkmann, B., Gill, P., Holland, M., Tully, G. \& M. Wilson, 2000: DNA Commission of the International Society for Forensic Genetics: guidelines for mitochondrial DNA typing.- Forensic Science International, 110, 2, 79-85. http://dx.doi.org/10.1016/s03790738(00)00161-4

Cave Cadastre, 2019: Cave Register of the Karst Research Institute ZRC SAZU and Speleological Association of Slovenia. Postojna, Ljubljana

Clark, T.R., Zhao, J.-X., Roff, G., Feng, Y.-X., Done, T.J., Nothdurft, L.D. \& J.M. Pandolfi, 2014: Discerning the timing and cause of historical mortality events in modern Porites from the Great Barrier Reef.- Geochimica et Cosmochimica Acta, 138, 57-80. http:// dx.doi.org/10.1016/j.gca.2014.04.022

Dabney, J., Knapp, M., Glocke, I., Gansauge, M.T., Weihmann, A., Nickel, B., Valdiosera, C., Garcia, N., Paabo, S., Arsuaga, J.L. \& M. Meyer, 2013: Complete mitochondrial genome sequence of a Middle Pleistocene cave bear reconstructed from ultrashort DNA fragments.- Proceedings of the National Academy of Sciences of the United States of America, 110, 39, 15758-15763. http://dx.doi.org/10.1073/ pnas. 1314445110

Desmarchelier, J., 2000: Stable isotope record and its palaeoenvironmental interpretation for a late Middle Pleistocene speleothem from Victoria Fossil Cave, Naracoorte, South Australia.- Quaternary Science Reviews, 19, 8, 763-774. http://dx.doi.org/10.1016/ s0277-3791(99)00037-2

Domínguez-Villar, D., Lojen, S., Krklec, K., Kozdon, R., Edwards, R.L. \& H. Cheng, 2018: Ion microprobe 
$\delta^{18} \mathrm{O}$ analyses to calibrate slow growth rate speleothem records with regional $\delta^{18} \mathrm{O}$ records of precipitation.- Earth and Planetary Science Letters, 482, 367376. http://dx.doi.org/10.1016/j.epsl.2017.11.012

Dorale, J.A., Edwards, R.L., Ito, E. \& L.A. Gonzalez, 1998: Climate and vegetation history of the midcontinent from 75 to $25 \mathrm{ka}$ : A speleothem record from crevice cave, missouri, USA.- Science, 282, 5395, 1871-1874. http://dx.doi.org/10.1126/science.282.5395.1871

Drysdale, R.N., Hellstrom, J.C., Zanchetta, G., Fallick, A.E., Sanchez Goni, M.F., Couchoud, I., McDonald, J., Maas, R., Lohmann, G. \& I. Isola, 2009: Evidence for obliquity forcing of glacial Termination II.- Science, 325, 5947, 1527-1531. http://dx.doi. org/10.1126/science.1170371

Fairchild, I.J. \& A. Baker, 2012: Speleothem Science: From Process to Past Environments.- Wiley Blackwell pp. 450, Chichester.

Ferk, M., 2016: Paleopoplave v porečju kraške Ljubljanice [Palaeofloods in karstic Ljubljanica River Catchment].- Anton Melik Geographical Institute ZRC SAZU pp. 187, Ljubljana.

Ferk, M., Lipar, M., Šmuc, A., Drysdale, R.N. \& J. Zhao, 2019: Chronology of heterogeneous deposits in the side entrance of Postojna Cave, Slovenia.- Acta geographica Slovenica, 59, 1, 103-116. http://dx.doi. org/10.3986/AGS.7059

Fortes, G.G., Grandal-d'Anglade, A., Kolbe, B., Fernandes, D., Meleg, I.N., Garcia-Vazquez, A., PintoLlona, A.C., Constantin, S., de Torres, T.J., Ortiz, J.E., Frischauf, C., Rabeder, G., Hofreiter, M. \& A. Barlow, 2016: Ancient DNA reveals differences in behaviour and sociality between brown bears and extinct cave bears.- Molecular Ecology, 25, 19, 49074918. http://dx.doi.org/10.1111/mec.13800

Gams, I., 1968: Prispevka k vprašanju starosti Postojnske jame.- Naše jame, 9, 32-36.

Gams, I., 1998: Geomorphogenetics of the Classical Karst - Kras.- Acta Carsologica, 27, 2, 181-198. http:// dx.doi.org/10.3986/ac.v27i2.509

Genty, D., Vokal, B., Obelic, B. \& M. Massault, 1998: Bomb ${ }^{14} \mathrm{C}$ time history recorded in two modern stalagmites - importance for soil organic matter dynamics and bomb ${ }^{14} \mathrm{C}$ distribution over continents.- Earth and Planetary Science Letters, 160, 3-4, 795-809. http://dx.doi.org/10.1016/s0012$821 x(98) 00128-9$

Genty, D., Blamart, D., Ouahdi, R., Gilmour, M., Baker, A., Jouzel, J. \& S. Van-Exter, 2003: Precise dating of Dansgaard-Oeschger climate oscillations in western Europe from stalagmite data.- Nature, 421, 6925, 833-837. http://dx.doi.org/10.1038/nature01391
Gillette, D.D., 1994: Seismosaurus : the earth shaker.- Columbia University Press pp. 205, New York.

Gillies, S.L., 2011: $\mathrm{CO}_{2}$ levels and Plants. What's So Wrong with a Greenhouse?.- In: Gillies, S.L. \& S. Hewitt (eds.) Biology on the Cutting Edge: Concepts, Issues, and Canadian Research around the Globe. Pearson Canada Inc., pp. 69-73, Canada.

Goede, A., 1998: Quaternary Studies of Caves and Coasts.$\mathrm{PhD}$ Thesis, University of Tasmania, pp. 330.

Gospodarič, R. \& P. Habič, 1966: Črni potok in Lekinka v sistemu podzemeljskega odtoka iz Pivške kotline.Naše jame, 8, 12-32.

Gospodarič, R., 1969: Speleološki procesi v Postojnski jami iz mlajšega pleistocena.- Naše jame, 10, 37-46.

Gospodarič, R., 1971: Prvi podatki o absolutni starosti sige v Postojnski jami na podlagi ${ }^{14} \mathrm{C}$.- Naše jame, 13, 91-98.

Gospodarič, R., 1981: Generacije sig v klasičnem krasu Slovenije (Sinter Generations in Classical Karst of Slovenia).- Acta Carsologica, 9, 90-110.

Hassan, A.A., Termine, J.D. \& C.V. Haynes, 1977: Mineralogical Studies On Bone Apatite and Their Implications for Radiocarbon Dating.- Radiocarbon, 19, 03, 364-374. http://dx.doi.org/10.1017/ s0033822200003684

Higgins, D. \& J.J. Austin, 2013: Teeth as a source of DNA for forensic identification of human remains: a review.- Science \& Justice, 53, 4, 433-441. http:// dx.doi.org/10.1016/j.scijus.2013.06.001

Hofreiter, M. \& M. Pacher, 2004: Using Ancient DNA to Elucidate Raw Material Origin of Bone Points from Potočka zijalka (Slovenia): Preliminary Results.Mitt. Komm. Quartärforsch. Österr. Akad. Wiss., 13, 201-210.

Hohenwart, F., 1830: Wegweiser für die Wanderer in der berühmten Adelsberger und Kronprinz FerdinandsGrotte bey Adelsberg in Krain pp., Ljubljana.

Höss, M., Jaruga, P., Zastawny, T.H., Dizdaroglu, M. \& S. Paabo, 1996: DNA Damage and DNA Sequence Retrieval from Ancient Tissues.- Nucleic Acids Research, 24, 7, 1304-1307. http://dx.doi.org/10.1093/ nar/24.7.1304

Ikeya, M., Miki, T. \& R. Gospodarič, 1983: ESR Dating of Postojna Cave Stalactite.- Acta Carsologica, 11, 117-130.

Jones, J.R., Marin-Arroyo, A.B., Straus, L.G. \& M.P. Richards, 2020: Adaptability, resilience and environmental buffering in European Refugia during the Late Pleistocene: Insights from La Riera Cave (Asturias, Cantabria, Spain).- Scientific Reports, 10, 1, 1217. http://dx.doi.org/10.1038/s41598-020-57715-2

Kendall, C., Eriksen, A.M.H., Kontopoulos, I., Collins, M.J. \& G. Turner-Walker, 2018: Diagenesis 
of archaeological bone and tooth.- Palaeogeography, Palaeoclimatology, Palaeoecology, 491, 21-37. http://dx.doi.org/10.1016/j.palaeo.2017.11.041

Komac, B., Pavšek, M. \& M. Topole, 2020. Climate and Weather of Slovenia. In: Perko, D., Ciglič, R. \& Zorn, M. (eds.). The Geography of Slovenia. Ljubljana, Springer, pp. 71-90.

Lebon, M., Reiche, I., Bahain, J.J., Chadefaux, C., Moigne, A.M., Fröhlich, F., Sémah, F., Schwarcz, H.P. \& C. Falguères, 2010: New parameters for the characterization of diagenetic alterations and heat-induced changes of fossil bone mineral using Fourier transform infrared spectrometry.- Journal of Archaeological Science, 37, 9, 2265-2276. http://dx.doi. org/10.1016/j.jas.2010.03.024

Lebon, M., Reiche, I., Gallet, X., Bellot-Gurlet, L. \& A. Zazzo, 2016: Rapid Quantification of Bone Collagen Content by ATR-FTIR Spectroscopy.- Radiocarbon, 58, 1, 131-145. http://dx.doi.org/10.1017/ rdc.2015.11

Lončar, N., Bar-Matthews, M., Avalon, A., Surić, M. \& S. Faivre, 2017: Early and mid-holocene environmental conditions in the eastern Adriatic recorded in speleothems from Mala Špilja cave and Velika Špilja cave (Mljet island, Croatia).- Acta Carsologica, 46, 2-3, 229-249. http://dx.doi.org/10.3986/ ac.v46i2-3.4939

Mandić, M., 2013: Determination of equilibrium conditions of carbonate precipitation in Postojna cave with possible application to paleoclimatology.- $\mathrm{PhD}$ Thesis. University of Zagreb, pp. 204.

McFarlin, S.C., Terranova, C.J., Zihlman, A.L. \& T.G. Bromage, 2016: Primary bone microanatomy records developmental aspects of life history in catarrhine primates.- Journal of Human Evolution, 92, 60-79. http://dx.doi.org/10.1016/j.jhevol.2015.12.004

Mihevc, A., 2002: Postojnska jama cave system, U/Th datation of the collapse processes on Velika Gora (Point 4).- In: Gabrovšek F. (ed.) Programme and guide booklet for the excursions: Evolution of Karst: from Prekarst to Cessation, $17^{\text {th }}-21^{\text {st }}$, September 2002, Postojna, 14-15, Karst Research Institute ZRC SAZU, Postojna.

Miller, W., Schuster, S.C., Welch, A.J., Ratan, A., BedoyaReina, O.C., Zhao, F., Kim, H.L., Burhans, R.C., Drautz, D.I., Wittekindt, N.E., Tomsho, L.P., IbarraLaclette, E., Herrera-Estrella, L., Peacock, E., Farley, S., Sage, G.K., Rode, K., Obbard, M., Montiel, R., Bachmann, L., Ingolfsson, O., Aars, J., Mailund, T., Wiig, O., Talbot, S.L. \& C. Lindqvist, 2012: Polar and brown bear genomes reveal ancient admixture and demographic footprints of past climate change.Proceedings of the National Academy of Sciences of the United States of America, 109, 36, E2382-2390. http://dx.doi.org/10.1073/pnas.1210506109

O'Neil, J.R., Clayton, R.N. \& T.K. Mayeda, 1969: Oxygen Isotope Fractionation in Divalent Metal Carbonates.- The Journal of Chemical Physics, 51, 12, 55475558. http://dx.doi.org/10.1063/1.1671982

Olsen, J., Heinemeier, J., Bennike, P., Krause, C., Margrethe Hornstrup, K. \& H. Thrane, 2008: Characterisation and blind testing of radiocarbon dating of cremated bone.- Journal of Archaeological Science, 35, 3, 791-800. http://dx.doi.org/10.1016/j. jas.2007.06.011

Päb̈bo, S., Poinar, H., Serre, D., Jaenicke-Despres, V., Hebler, J., Rohland, N., Kuch, M., Krause, J., Vigilant, L. \& M. Hofreiter, 2004: Genetic analyses from ancient DNA.- Annual Review of Genetics, 38, 645-679. http://dx.doi.org/10.1146/annurev.genet.37.110801.143214

Pacher, M. \& A.J. Stuart, 2009: Extinction chronology and palaeobiology of the cave bear (Ursus spelaeus).Boreas, 38, 2, 189-206. http://dx.doi.org/10.1111/ j.1502-3885.2008.00071.x

Pawłowska, J., Lejzerowicz, F., Esling, P., Szczuciński, W., Zajączkowski, M. \& J. Pawlowski, 2014: Ancient DNA sheds new light on the Svalbard foraminiferal fossil record of the last millennium.- Geobiology, 12, 4, 277-288. http://dx.doi.org/10.1111/gbi.12087

Perko, D., Hrvatin, M. \& R. Ciglič, 2015: A methodology for natural landscape typification of Slovenia.- Acta geographica Slovenica, 55, 2, 235-270. http://dx.doi. org/10.3986/ags. 1938

Perko, D., Hrvatin, M. \& R. Ciglič, 2017: Determination of landscape hotspots of Slovenia.- Acta geographica Slovenica, 57, 1, 7-29. http://dx.doi.org/10.3986/ ags. 4618

Perko, G.A., 1910: Die Adelsberger Grotte in Wort und Bild pp., Postojna.

Pipan, T., Petrič, M., Šebela, S. \& D.C. Culver, 2019: Analyzing climate change and surface-subsurface interactions using the Postojna Planina Cave System (Slovenia) as a model system.- Regional Environmental Change, 19, 379-389. http://dx.doi. org/10.1007/s10113-018-1349-Z

Pleničar, M., Ogorelec, B. \& M. Novak, 2009: Geologija Slovenije [The Geology of Slovenia].- Geološki zavod Slovenije, pp. 612, Ljubljana.

Poinar, H.N., Hoss, M., Bada, J.L. \& S. Pääbo, 1996: Amino Acid Racemization and the Preservation of Ancient DNA.- Science, 272, 5263, 864-866. http:// dx.doi.org/10.1126/science.272.5263.864

Putkonen, M.T., Palo, J.U., Cano, J.M., Hedman, M. \& A. Sajantila, 2010: Factors affecting the STR amplification success in poorly preserved bone sam- 
ples.- Investigative Genetics, 1, 1, 9. http://dx.doi. org/10.1186/2041-2223-1-9

Qiagen Companies, 2014: EZ1 DNA Investigator Handbook.- Qiagen, pp. 48, Hilden.

Rabeder, G. \& G. Withalm, 2001: The Križna jama near Lož in the classic karst. $7^{\text {th }}$ International Symposium on Cave Bear, Excursion Guide, 1-4, Opicina.

Rabeder, G., Hofreiter, M., Nagel, D. \& G. Withalm, 2004a: New taxa of alpine cave bears (Ursidae, Carnivora).- In: Philippe, M. et al. (eds.) Proceedings of the $9^{\text {th }}$ International Cave Bear Conference. Cahiers scientifiques du Centre de Conservation et d'Etude des Collections Muséum d'Histoire naturelle de Lyon, pp. 49-68.

Rabeder, G., Hofreiter, M. \& G. Withalm, 2004b: The Systematic Position of the Cave Bear from Potočka zijalka (Slovenia).- Mitteilungen der Kommission für Quartärforschung der Österreichischen Akademie der Wissenschaften, 13, 197-200.

Rabeder, G., Hofreiter, M. \& M. Stiller, 2011: Chronological and systematic position of cave bear fauna from Adjovska jama near Křsko (Slovenia).- Mitteilungen der Kommission für Quartärforschung der Österreichischen Akademie der Wissenschaften, 20, 79-85.

Rakovec, I., 1954: Povodni konj iz Pivške kotline.- SAZU, Razred za prirodoslovne vede, Razprave, II, 299317, Ljubljana.

Rawlence, N.J., Lowe, D.J., Wood, J.R., Young, J.M., Churchman, G.J., Huang, Y.-T. \& A. Cooper, 2014: Using palaeoenvironmental DNA to reconstruct past environments: progress and prospects.- Journal of Quaternary Science, 29, 7, 610-626. http://dx.doi. org/10.1002/jqs. 2740

Robu, M., 2016: Age re-assessment of the cave bear assemblage from Urşilor Cave, north-western Romania.- International Journal of Speleology, 45, 2, 123133. http://dx.doi.org/10.5038/1827-806x.45.2.1947

Rohland, N. \& M. Hofreiter, 2007: Ancient DNA extraction from bones and teeth.- Nature Protocols, 2, 7, 1756-1762. http://dx.doi.org/10.1038/ nprot.2007.247

Schmidl, A., 1854: Die Grotten und Höhlen von Adelsberg, Lueg, Planina und Laas.- pp. 316, Vienna.

Scholz, D. \& D.L. Hoffmann, 2011: StalAge - An algorithm designed for construction of speleothem age models.- Quaternary Geochronology, 6, 3-4, 369382. http://dx.doi.org/10.1016/j.quageo.2011.02.002

Šebela, S., 1998: Tectonic structure of Postojnska jama cave system (Tektonska zgradba sistema Postojnskih jam).- Založba ZRC SAZU, pp. 112, Ljubljana.

Šebela, S. \& I.D. Sasowsky, 1999: Age and Magnetism of Cave Sediments from Postojnska jama Cave System and Planinska jama Cave, Slovenia.- Acta Carsologica, 28, 2. http://dx.doi.org/10.3986/ac.v28i2.498

Šebela, S. \& J. Turk, 2011a: Air temperature characteristics of the Postojna and Predjama cave systems.Acta geographica Slovenica, 51, 1, 43-64. http:// dx.doi.org/10.3986/ags51102

Šebela, S. \& J. Turk, 2011b: Local characteristics of Postojna Cave climate, air temperature, and pressure monitoring.- Theoretical and Applied Climatology, 105, 3-4, 371-386. http://dx.doi.org/10.1007/ s00704-011-0397-9

Shaw, T. \& A. Čuk, 2015: Slovene Karst and Caves in the Past.- Založba ZRC, pp. 464, Ljubljana.

Shtober-Zisu, N., Schwarcz, H., Chow, T., Omelon, C. \& G. Southam, 2014: Caves in caves: evolution of postdepositional macroholes in stalagmites.- International Journal of Speleology, 43, 3, 323-334. http:// dx.doi.org/10.5038/1827-806x.43.3.9

Smith, C.I., Chamberlain, A.T., Riley, M.S., Stringer, C. \& M.J. Collins, 2003: The thermal history of human fossils and the likelihood of successful DNA amplification.- Journal of Human Evolution, 45, 3, 203-217. http://dx.doi.org/10.1016/s0047-2484(03)00106-4

Snoeck, C., Lee-Thorp, J.A. \& R.J. Schulting, 2014: From bone to ash: Compositional and structural changes in burned modern and archaeological bone.- Palaeogeography, Palaeoclimatology, Palaeoecology, 416, 55-68. http://dx.doi.org/10.1016/j. palaeo.2014.08.002

Stepišnik, U., 2004: The origin of sediments inside the collapse dolines of Postojna karst (Slovenia).- Acta Carsologica, 33, 1, 237-244. http://dx.doi.org/https://doi.org/10.3986/ac.v33i1.326

Stepišnik, U., 2017: Dinarski kras: plitvi kras Zgornje Pivke [The Dinaric Karst: Shallow Karst of Upper Pivka].- Znanstvena založba Filozofske fakultete, pp. 116, Ljubljana.

Surovell, T.A. \& M.C. Stiner, 2001: Standardizing Infrared Measures of Bone Mineral Crystallinity: an Experimental Approach.- Journal of Archaeological Science, 28, 6, 633-642. http://dx.doi.org/10.1006/ jasc. 2000.0633

Thompson, T.J.U., Gauthier, M. \& M. Islam, 2009: The application of a new method of Fourier Transform Infrared Spectroscopy to the analysis of burned bone.- Journal of Archaeological Science, 36, 3, 910914. http://dx.doi.org/10.1016/j.jas.2008.11.013

Trueman, C.N.G., Behrensmeyer, A.K., Tuross, N. \& S. Weiner, 2004: Mineralogical and compositional changes in bones exposed on soil surfaces in Amboseli National Park, Kenya: diagenetic mechanisms and the role of sediment pore fluids.- Journal of Ar- 
chaeological Science, 31, 6, 721-739. http://dx.doi. org/10.1016/j.jas.2003.11.003

Turner-Walker, G., 2008: The chemical and microbial degradation of bones and teeth.- In: Pinhasi, R. \& S. Mays (eds.) Advances in Human Palaeopathology, John Wiley and Sons LTD, pp. 1-29, Chichester.

Turner-Walker, G. \& S. Mays, 2008: Histological Studies on Ancient Bone.- In: Pinhasi, R. \& Mays, S. (eds.) Advances in Human Palaeopathology. John Wiley \& Sons, LTD, pp. 121-146, Chichester.

Valvasor, J.W., 1689: Die Ehre dess Hertzogthums Crain pp., Ljubljana.

Van Meerbeeck, C.J., Renssen, H. \& D.M. Roche, 2009: How did Marine Isotope Stage 3 and Last Glacial Maximum climates differ? - Perspectives from equilibrium simulations.- Climate of the Past, 5, 1, 33-51. http://dx.doi.org/10.5194/cp-5-33-2009

Veitschegger, K., Kolb, C., Amson, E., Scheyer, T.M. \& M.R. Sanchez-Villagra, 2018: Palaeohistology and life history evolution in cave bears, Ursus spelaeus sensu lato.- PLoS One, 13, 11, e0206791. http:// dx.doi.org/10.1371/journal.pone.0206791

Vreča, P., Krajcar Bronić, I., Leis, A. \& M. Brenčič, 2008: Isotopic composition of precipitation in Ljubljana (Slovenia).- Geologija, 51, 2, 169-180. http://dx.doi. org/10.5474/geologija.2008.018

Vreča, P., Krajcar Bronić, I. \& A. Leis, 2011: Isotopic composition of precipitation in Portorož (Slovenia).Geologija, 54, 1, 129-138. http://dx.doi.org/10.5474/ geologija.2011.010

Vreča, P., Krajcar Bronić, I. \& A. Leis, 2015: Isotopic composition of precipitation at the station Portorož, Slovenia - period 2007-2010.- Geologija, 58, 2, 233246. http://dx.doi.org/10.5474/geologija.2015.019

Vreča, P., Krajcar Bronić, I., Leis, A. \& M. Demšar, 2014: Isotopic composition of precipitation at the station Ljubljana (Reaktor), Slovenia - period 2007-2010.Geologija, 57, 2, 217-230. http://dx.doi.org/10.5474/ geologija.2014.019

Vreča, P. \& N. Malenšek, 2016: Slovenian Network of Isotopes in Precipitation (SLONIP) - a review of activities in the period 1981-2015.- Geologija, 59, 1, 67-84. http://dx.doi.org/10.5474/geologija.2016.004
Weiner, S. \& O. Bar-Yosef, 1990: States of preservation of bones from prehistoric sites in the Near East: A survey.- Journal of Archaeological Science, 17, 2, 187-196. http://dx.doi.org/10.1016/03054403(90)90058-d

Wilson, M.R., DiZinno, J.A., Polanskey, D., Replogle, J. \& B. Budowle, 1995: Validation of mitochondrial DNA sequencing for forensic casework analysis.International Journal of Legal Medicine, 108, 2, 6874. http://dx.doi.org/10.1007/bf01369907

Wright, L.E. \& H.P. Schwarcz, 1996: Infrared and Isotopic Evidence for Diagenesis of Bone Apatite at Dos Pilas, Guatemala: Palaeodietary Implications.- Journal of Archaeological Science, 23, 6, 933-944. http:// dx.doi.org/10.1006/jasc.1996.0087

Zhang, Z., Schwartz, S., Wagner, L. \& W. Miller, 2000: A greedy algorithm for aligning DNA sequences.Journal of Computational Biology, 7, 1-2, 203-214. http://dx.doi.org/10.1089/10665270050081478

Zhou, H., Zhao, J., Qing, W., Feng, Y. \& J. Tang, 2011: Speleothem-derived Asian summer monsoon variations in Central China, 54-46ka.- Journal of Quaternary Science, 26, 8, 781-790. http://dx.doi. org/10.1002/jqs. 1506

Zupan Hajna, N., Pruner, P., Mihevc, A., Schnabl, P. \& P. Bosák, 2008: Cave Sediments from PostojnskaPlaninska Cave System (Slovenia): Evidence of Multi-Phase Evolution in Epiphreatic Zone.- Acta Carsologica, 37, 1, 63-86. http://dx.doi.org/10.3986/ ac.v37i1.160

Zupan Hajna, N., Bosák, P., Pruner, P., Mihevc, A., Hercman, H. \& I. Horáček, 2019: Karst sediments in Slovenia: Plio-Quaternary multi-proxy records.Quaternary International, 546, 4-19. http://dx.doi. org/10.1016/j.quaint.2019.11.010

Zupanič Pajnič, I., 2016. Extraction of DNA from Human Skeletal Material.- In: Goodwin, W. (ed.) Forensic DNA Typing Protocols. Springer, Humana Press, pp. 89-108, New York. http://dx.doi.org/10.1007/9781-4939-3597-0_710.1007/978-1-4939-3597-0_7 